\title{
REPRODUCTIVE MECHANISM OF UNISEXUAL AND BISEXUAL STRAINS OF THE VIVIPAROUS FISH POECILIOPSIS ${ }^{1}$
}

\author{
R. JACK Schultz \\ Museum of Zoology, The University of Michigan
}

Received September 12, 1960

The fishes of the order Cyprinodontiformes have evolved a variety of systems of sex-determination, some of which are unique among vertebrate animals. One such anomalous condition was recently reported by Miller and Schultz (1959) in the viviparous genus Poeciliopsis Regan, wherein certain strains gave birth to only female offspring. Poeciliopsis comprises approximately 16 species that range from southern Arizona to Colombia, with at least two endemics in the Atlantic drainage of the Isthmus of Tehuantepec (fig. 1). Western Mexico harbors the largest number of species.

This study deals principally with two species of Poeciliopsis tentatively assigned to the species group Leptorhaphis Regan (Miller, 1960). Since neither species has been described, ${ }^{2}$ they are here assigned the symbolic designations "C" and "F." Poeciliopsis " $\mathrm{C}$ " is found in southern Sonora and northern Sinaloa, where it is confined to the Mocorito, Sinaloa, and Fuerte river drainages. The southern limit of " $F$ " is less than 50 miles to the north; it extends from the Rio Mayo northward to the Yaqui, Matape, Sonora, and Concepción rivers in Sonora.

From preserved material collected within the range of strain "F," Miller was able to identify females with two types of dentition. One of these is considered to be the normal type in that the minute inner teeth are like those of the male. They consist of

\footnotetext{
${ }^{1}$ Part of a thesis submitted to The University of Michigan in partial fulfillment of the requirements for the degree of Doctor of Philosophy, June, 1960. Cost of extra pages paid for by the author.

'Since this was written, the species here referred to " $\mathrm{C}$ " and " $\mathrm{C}_{\mathrm{x}}$ " has been described as Poeciliopsis lucida; the one designated " $F$ " and "F" may be identical with $P$. occidentalis (Miller, 1960).
}

Evolutron 15: 302-325. September, 1961

one or two uneven rows that follow the heart-shaped curvature of the lips and the outer row of teeth. The second type of dentition is characteristic of an aberrant strain of " $F$ " females which are designated as " $F_{x}$ " The inner teeth of this strain consist of a fine sandpaper-like patch on either side of the midline. No other consistent morphological differences have been found between the two strains, yet reproductively they are radically different. Matings of " $F$ " females having normal dentition to " $F$ " males result in young of both sexes, but the " $F_{x}$ " females with aberrant dentition mated to the same male produce only female progeny.

The same aberrant dental character was later found in samples of strain "C." In these, however, dentition proved to be less reliable for distinguishing the unisexual strain, designated " $\mathrm{C}_{x}$," from the normal females. Offspring from " $\mathrm{C}_{\mathrm{x}}$ " individuals showed a spectrum of variation from the nearly normal to the aberrant types of dentition. These progeny were nevertheless all females, as were the succeeding generations.

This "all-female" phenomenon appears to be similar to that discovered by Hubbs and Hubbs (1932) in Mollienesia formosa, a member of the same family as Poeciliopsis.

It is the purpose of this study to find the sex-determining mechanism responsible for unisexuality in Poeciliopsis. Aspects of the reproductive biology and genetics of both the bisexual and the unisexual types, therefore, have been studied and comparisons have been made with other animals known to have unusual sex-ratios. The following mechanisms have been considered: lethal systems, polyploidy, parthenogenesis, gynogenesis, sex-inversion, cytoplasmic in- 


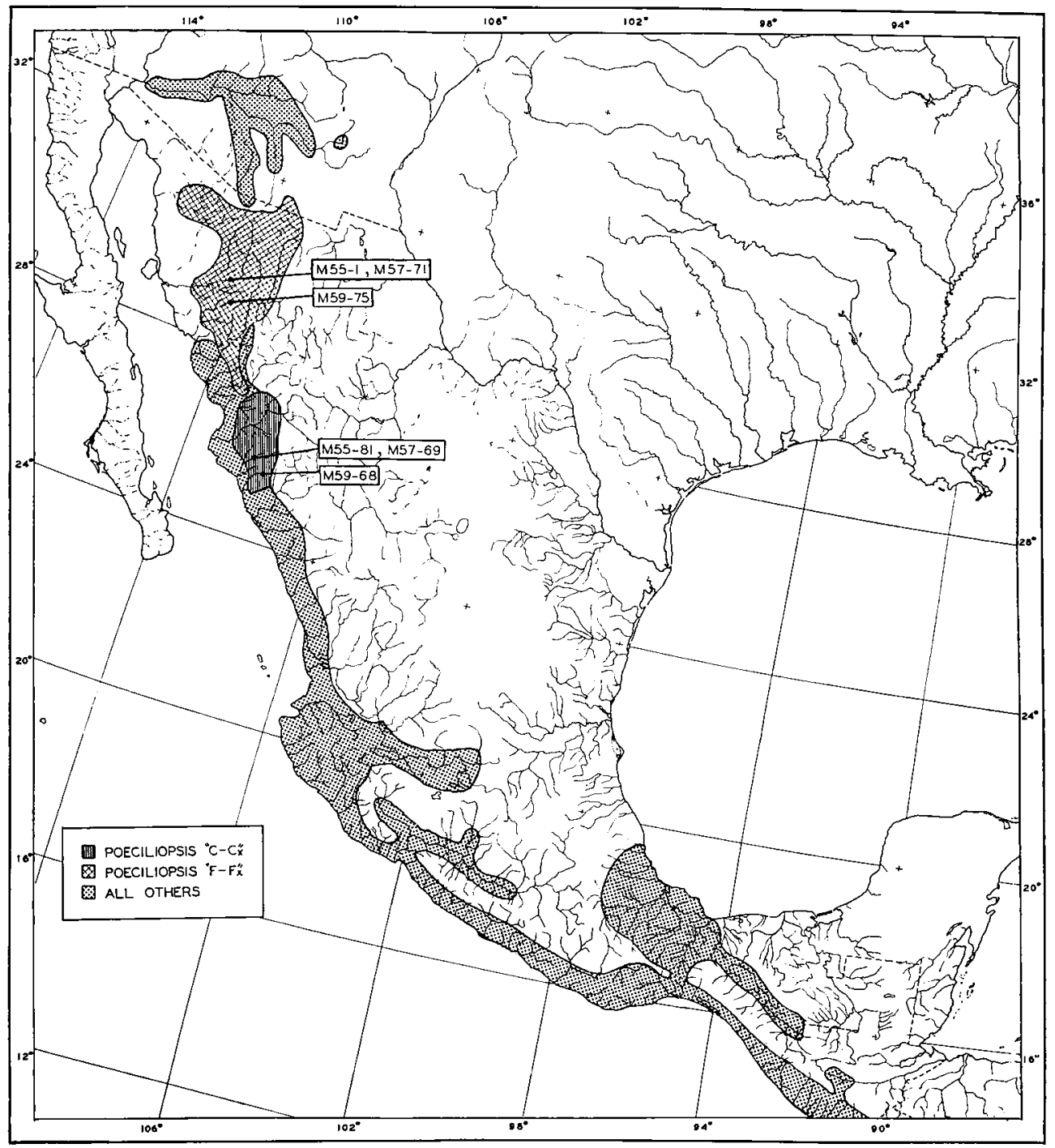

Fig. 1. Distribution of Poeciliopsis in part of North America, showing localities from which live stocks were obtained.

heritance, unbalanced autosomal system, and selective maturation.

\section{Materials and Methods}

Live stocks used in this investigation were collected in northwestern Mexico during expeditions by Miller and Greenbank in 1955, Miller and Miller in 1957, and Miller and Schultz in 1959. The localities from which they were obtained are indi- cated in fig. 1 by collecting station numbers.

Specimens to be used for genetic analysis or to be dissected for gonadal studies were fixed in $10 \%$ formalin and preserved in $70 \%$ ethyl alcohol. Examination of live material was facilitated by the use of an anesthetic, MS-222 (Tricaine methanesulfonate). Immature fish used in histological studies were killed and fixed in 
Bouin's solution and preserved in $70 \%$ alcohol. The entire fish was embedded in paraffin and sections were cut at $10 \mathrm{mi}$ crons. These were stained in Ehrlich's haematoxylin and counterstained with eosin, and were examined at magnifications of $430 \mathrm{x}$ and $980 \mathrm{x}$. Cytological preparations were made from embryos one or two days old and from testes of adult males. The tissue was killed and fixed in Newcomer's solution, stained in aceto-carmine and squashed between cover slip and slide. All fish measurements are the total length in $\mathrm{mm}$ estimated to the nearest tenth.

\section{Reproductive Biology}

Insemination.-Poeciliopsis, being a viviparous fish, has internal fertilization. Spermatophores or sperm packets are placed in the genital pore of the female by means of the male's modified anal fin, the gonopodium. Here, the packets break up, releasing the spermatozoa. These migrate up the gonaduct to the ovary where they remain viable for months. As a result of sperm storage, Poeciliopsis females may produce as many as ten broods of young after they have been isolated from their mates.

Ovarian Cycle.-Most viviparous fishes have only one stage of embryos in the ovary at a time: the birth of these must take place before the next series of ova is fertilized. Poeciliopsis, however, has superfetation, wherein two or more stages of embryos develop simultaneously (Turner, 1937).

From the brood records and from the examination of more than 400 females, a generalized sequence of events occurring within the ovary has been reconstructed. Except for minor deviations it seems applicable to all species of Poeciliopsis.

Ovaries of submature females contain several strings of tiny, white oocytes, .25 to $.30 \mathrm{~mm}$ in diameter. As the female matures, one or two of these oocytes begin to accumulate yolk, which gives them an amber color. The nucleus is centrally located in these submature eggs; but upon completion of yolk deposition, it migrates to the periphery, where maturation division occurs.

After this series of eggs is fertilized, yolk accumulates in a second series. By the time the first embryos are 7 to 10 days old and have reached the halfway point in their development, the second series of ova is fertilized. In strains " $\mathrm{C}$ " and " $\mathrm{C}_{\mathbf{x}}$ " the blastula or streak stage of a third brood of embryos is sometimes found before the birth of the first or oldest stage of embryos, but in " $F$ " and " $F_{x}$ " no more than two stages of embryos occur at one time.

If sperm are not available to fertilize the newly matured ova the condition does not remain static but degeneration of the ova ensues. Degenerating ova and embryos are common in females living under suboptimum conditions or in those used in certain hybrid crosses. Frequently one to several ova of a clutch fail to become fertilized or an embryo dies in the course of its development. The age of these can be correlated with the brood of embryos of which they normally would have been a part. Degenerating elements in the ovary can be recognized for more than two weeks after their death.

In dealing with unisexual animals, one of the concerns is whether or not the one sex dies before maturity. A more complete evaluation of lethals as they relate to the unisexual strains of Poeciliopsis will be considered later, but certain aspects that involve the ovary are treated appropriately here.

In a reproductive system such as that of viviparous fishes, a lethal mechanism acting during the intraovarian cycle would reveal itself by the presence of dead embryos, eggs, or oocytes. In " $\mathrm{C}_{x}$ " and " $\mathrm{F}_{\mathrm{x}}$," a sufficient number of failures to account for unisexuality might be expected at any of the following stages of the ovarian cycle: (1) maturation division; (2) fertilization; (3) early cleavage; and (4) advanced embryos. In "C" and " $F$ " no more than a few prenatal deaths theoretically should occur.

From the 38 " $\mathrm{C}$ " and " $\mathrm{C}_{\mathbf{x}}$ " females dis- 
TABLE 1. Comparison of intraovarian mortality between strains " $C$ " and " $C_{x}$ "

\begin{tabular}{cccc}
\hline $\begin{array}{c}\text { Strain of } \\
\text { female }\end{array}$ & $\begin{array}{c}\text { Number } \\
\text { dissected }\end{array}$ & $\begin{array}{c}\text { Ova and } \\
\text { embryos } \\
\text { observed }\end{array}$ & $\begin{array}{c}\text { Per cent } \\
\text { of } \\
\text { mortality }\end{array}$ \\
\hline $\mathrm{C}$ & 11 & 102 & 21.7 \\
$\mathrm{C}_{\mathbf{x}}$ & 27 & 319 & 5.6 \\
\hline
\end{tabular}

sected for this phase of the study, only a few dead embryos could be found. The degenerating elements observed were for the most part identified as ova. Many of these, however, were undoubtedly early embryos undetected because of their small size and degenerate condition. When the total intraovarian mortality of " $\mathrm{C}$ " and " $\mathrm{C}_{x}$ " was compared (table 1 ), the unisexual strain actually had fewer degenerating elements $(5.6 \%)$ than did the bisexual strain $(21.7 \%)$. A study of the aquarium history of each female revealed that all of those containing more than one dead ovum or embryo had been subjected to suboptimal rearing conditions such as inadequate illumination or overcrowding. Since strain " $C$ " is in general less hardy than " $\mathrm{C}_{x}$," the higher mortality rate in the ovaries of these fish is accountable. When individuals of both strains are maintained under ideal conditions, intraovarian failures are almost negligible. It must, therefore, be assumed that if differential mortality is responsible for unisexuality in this genus, it takes place during a later stage of development.

Brood Intervals and Brood Sizes.-Development of superfetation in poeciliid fishes has significantly reduced brood intervals and brood sizes. In Lebistes and similar forms that lack superfetation, as many as 75 young are born at intervals of 22 to 30 days, whereas species with two or three stages of embryos seldom have more than 25 young per brood. These are born at intervals of 7 to 14 days.

Normally there is little fluctuation in the brood interval of healthy Poeciliopsis females; but in compiling extensive data for comparing species or strains, some distorting features must be taken into account. Occasionally a single young from a brood
TABLE 2. Minimum and average brood interval in days of strains " $C$," " $C_{x}, "$ " $F$," and " $F_{x}$ "

\begin{tabular}{lccc}
\hline \hline $\begin{array}{c}\text { Strain of } \\
\text { female }\end{array}$ & $\begin{array}{c}\text { Sample } \\
\text { size }\end{array}$ & $\begin{array}{c}\text { Minimum } \\
\text { brood } \\
\text { interval }\end{array}$ & $\begin{array}{c}\text { Average } \\
\text { brood } \\
\text { interval }\end{array}$ \\
\hline$P . \mathrm{C}$ & 182 & 4 & 11.5 \\
$P . \mathrm{C}_{\mathbf{x}}$ & 124 & 7 & 11.7 \\
$P . \mathbf{F}$ & 26 & 5 & 13.8 \\
$P . \mathbf{F}_{\mathbf{x}}$ & 76 & 9 & 13.2 \\
\hline
\end{tabular}

is retained in the ovary and is not born until one or two days after the others. Females in poor condition have irregular intervals, but even healthy individuals experience interruption or "rest periods" after a long sequence of births. Although more typical of winter months, long brood intervals also may occur during the summer. The above irregularities were disposed of by considering only those intervals that fell between 4 and 20 days (table 2 ). Comparison of the average brood intervals of the four strains of females revealed no significant difference between the 11.5 day interval of " $\mathrm{C}$ " and the 11.7 day interval of " $\mathrm{C}_{x}$ ", nor was there any difference between the 13.8 and 13.2 day intervals of " $F$ " and " $F_{x}$." The occasional presence of three stages of embryos in the ovaries of " $\mathrm{C}$ " and " $\mathrm{C}$ " is reflected in the shorter brood intervals of these two strains.

Brood size data are difficult to evaluate. Not only does the number of young in broods from a single female sometimes vary for no apparent reason, but environmental factors also affect the reproductive condition of the fish. In Poeciliopsis, inadequate illumination, even during early life, may reduce the reproductive capacity of females. Artificial light sufficient to produce a plankton bloom does not compare with natural light for rearing Poeciliopsis young. Overcrowding and peck-order dominance result in stunted fish which, upon reaching adulthood, may have reduced fecundity. These factors are so complex as to constitute a separate study and will not be pursued here.

In order to obtain at least some notion of the reproductive potential of Poeciliop- 


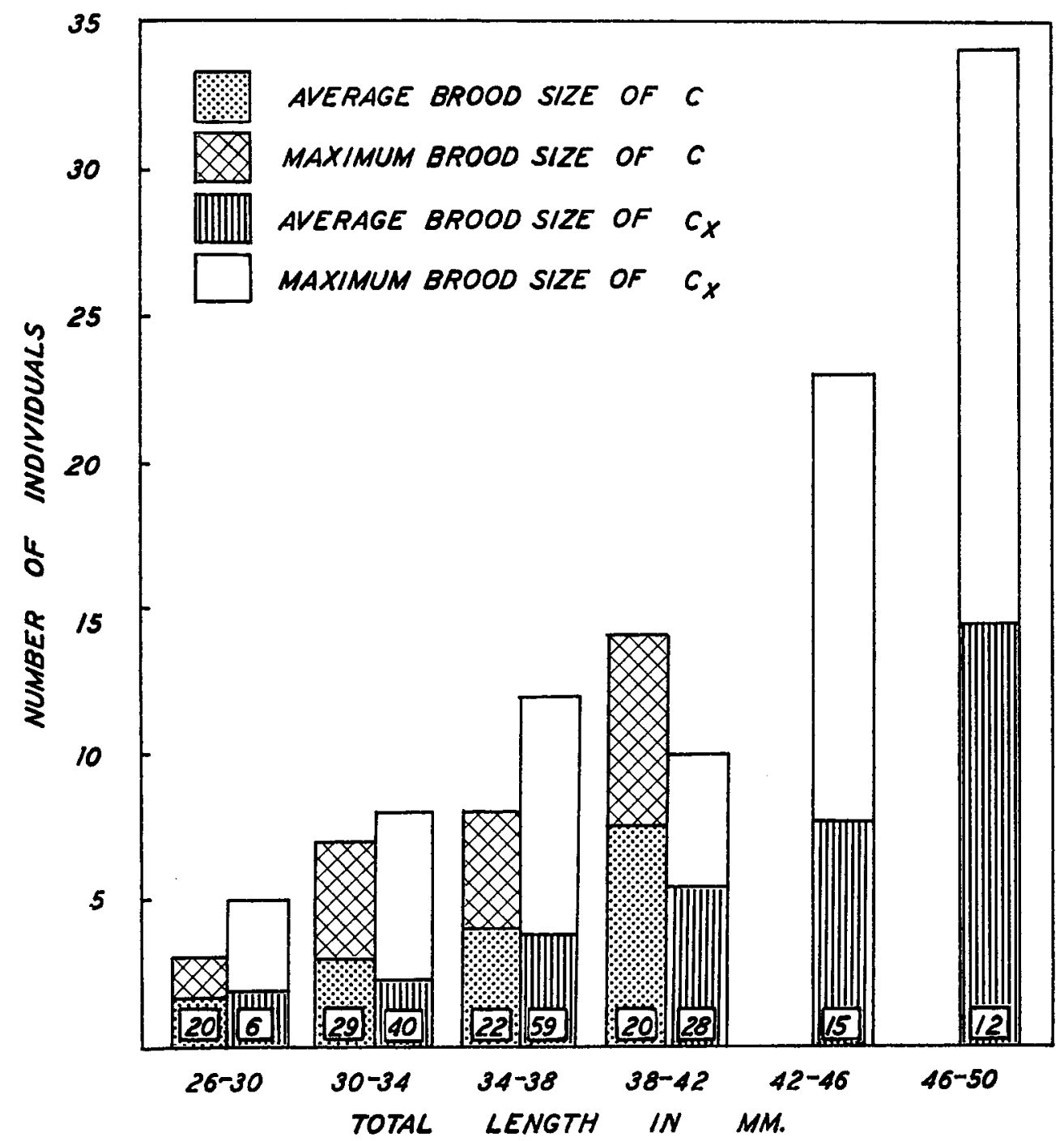

Fig. 2. Average and maximum brood sizes of " $C$ " and " $C_{x}$ " females in relation to the total length of the female. The sample size of each class is indicated in the square on each bar.

sis, females of each type were anesthetized and measured after the birth of young. The average and maximum brood for females of various size classes are presented in figures 2 and 3 . Although certain size classes are poorly represented, particularly for " $F$ " and " $F_{x}$, " several interesting tendencies are apparent. In comparing strains " $\mathrm{C}$ " and " $\mathrm{C}_{\mathrm{x}}$ " " the expected trend of larger females to have larger broods is evident. The two strains behave differently, however, in that " $C$ " reaches its maximum brood size and stops reproducing at about $41 \mathrm{~mm}$, whereas " $\mathrm{C}_{x}$ " continues to have young until about $50 \mathrm{~mm}$ long. In these size ranges " $\mathrm{C}_{\mathbf{x}}$ " has produced broods with far more young than any other species of Poeciliopsis reared in this laboratory. Four such broods contained 34, 23, 21, and 19 offspring. Only " $C$ " has approached this record, with broods of $16,14,12$, and 12 . Since only two size classes of " $F$ " are rep- 


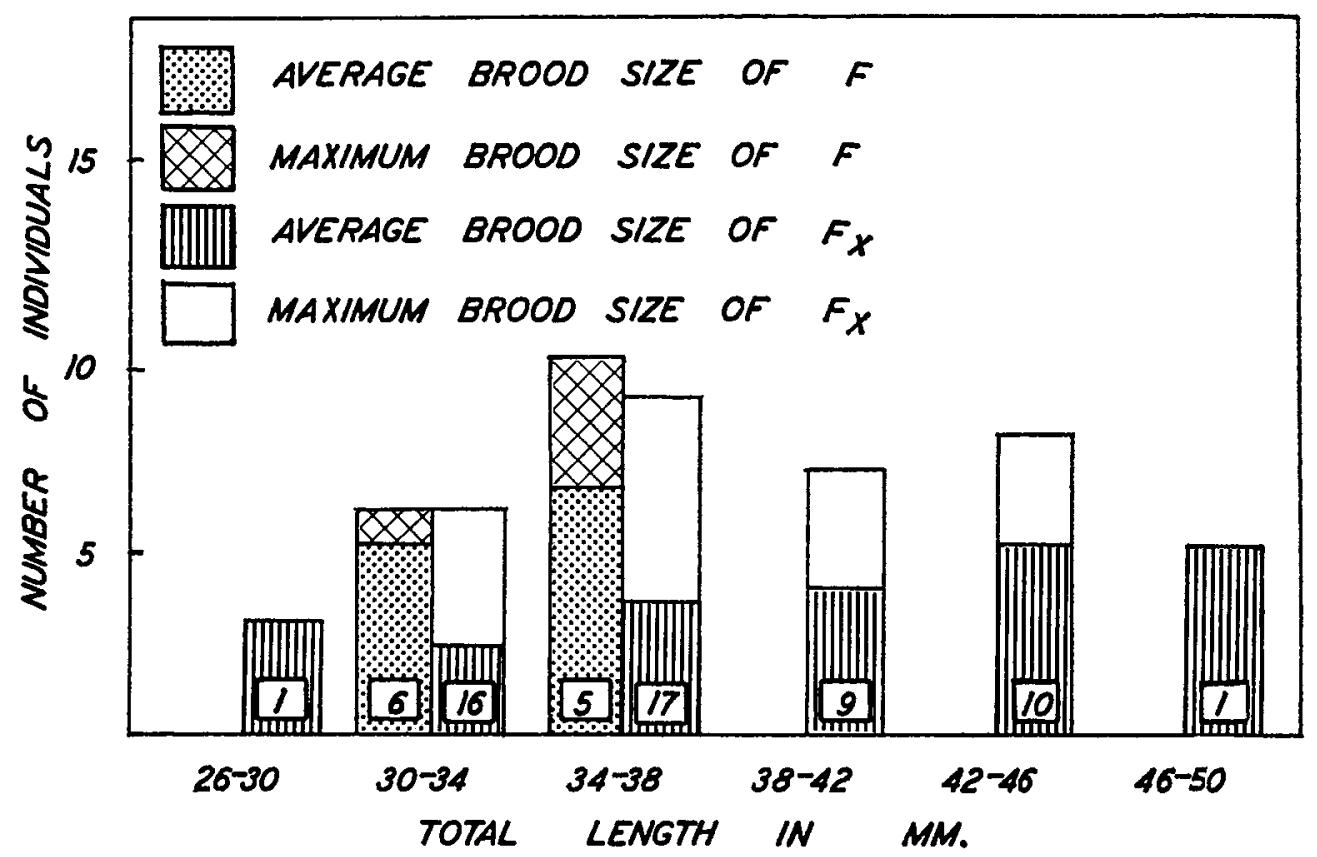

FIG. 3. Average and maximum brood size of "F" and " $F_{x}$ " females in relation to the total length of the female. The sample size of each class is indicated in the square on each bar.

resented, all that can be said of the reproductive potential of this species is that the maximum brood consisted of 10 youngthese by a $36.4 \mathrm{~mm}$ female (fig. 3). Although the data for " $F_{\mathbf{x}}$ " are somewhat scanty, this strain apparently produces fewer young in the laboratory than either " $C$ " or " $\mathrm{C}_{\mathrm{x}}$." " $\mathrm{F}_{\mathrm{x}}$ " females do, however, attain nearly the same maximum length as the " $\mathrm{C}_{\mathbf{x}}$ " females. It is also possible that " $F_{x}$ " produces fewer young than " $F$," but more information is required to clarify this point.

Maturation and Senescence.-The attainment of sexual maturity in Poeciliopsis females is not accompanied by apparent external changes. Therefore, dissection was required in order to determine the age or size at which females become adults. Ovaries from aquarium-reared individuals of various ages and sizes were examined. Those with at least one mature or degenerating ovum were considered fully developed, whereas the presence of only oocytes, whether or not they contained yolk, was interpreted as evidence of immaturity.

The various species and strains of Poeciliopsis differ in the size and age at which they mature. Of the four types considered here, " $C$ " is the smallest. Females of this strain have mature ova when 20 to $22 \mathrm{~mm}$ long and at an age of 49 days. The youngest to reproduce were 69 days old and 21 to $23 \mathrm{~mm}$ long. Strain " $\mathrm{C}_{\mathbf{x}}$ " matures at 21 to $24 \mathrm{~mm}$ and at a minimum age of 70 days-20 days older than "C."

Females of strains " $F$ " and " $F_{x}$ " matured at a minimum size of $23 \mathrm{~mm}$ and at an age of more than two months; no young were born prior to the attainment of 29.9 $\mathrm{mm}$. The variations and discrepancies among individuals, however, indicate that in these strains, particularly in " $F$," factors influencing gonad development are more complex than those involved in either " $C$ " or " $\mathrm{C}_{\mathrm{x}}$." Five of the " $\mathrm{F}$ " females examined exceeded $25 \mathrm{~mm}$; yet only one of these contained ova. Certainly their size should have been sufficient for gonadal 


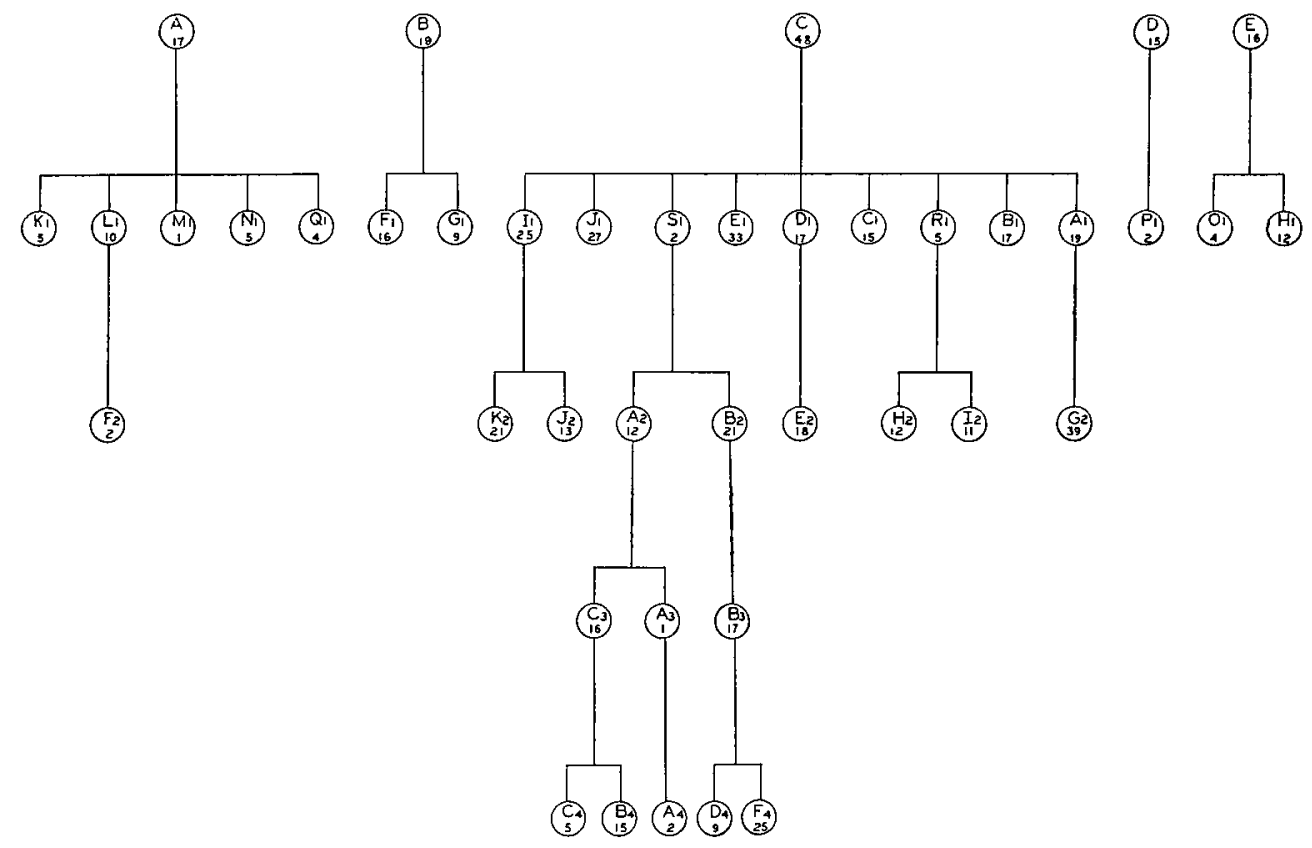

Frg. 4. Descendants of five wild " $\mathrm{C}_{\mathbf{x}}$ " females from M57-69. Letter $=$ female designation; subscript $=$ laboratory generation; number $=$ offspring from each female that were raised to maturity. All young that matured were females.

maturation. There is some evidence that females born during the summer do not mature until early spring of the following year.

Strains "C" and " $\mathrm{C}_{\mathbf{x}}$ " differ not only in the size and length at which they mature but also in the maximum length attained. Females of " $C$ " reach their maximum length at about $43 \mathrm{~mm}$, whereas " $\mathrm{C}_{\mathbf{x}}$ " females not uncommonly exceed this by more than $5 \mathrm{~mm}$. " $\mathrm{F}$ " females were smaller than those of the other three strains. Their condition, however, probably reflected the effects of aquarium life, since specimens collected in nature and placed in the aquarium had lengths of 40 to $43 \mathrm{~mm}$, approaching the maximum for " $F_{x}$." The largest of the " $F_{x}$ " females had total lengths of about 46 $\mathrm{mm}$.

Females of most species of Poeciliopsis reared under optimum conditions live for about a year and a half; 678 days was the maximum age attained by any individual. No great difference was found in the longevity of the four strains.
The number of days required for males to mature, as evidenced by gonopodial development, varied considerably among individuals and species. " $\mathrm{C}$ " males on the average reached adulthood in approximately half the time required for " $F$ " -68 versus 142 . Once mature, the males stop growing. No significant change in length could be demonstrated over a period of five to nine months for five adult males of Poeciliopsis "C." The total life span for males of each species is about one year, but a few individuals have lived more than a year and a half.

\section{EXPERIMENTAL RESULTS}

Intraspecific Matings and Sex-Ratios of Offspring.-Although it is known that certain Poeciliopsis females give birth only to female offspring whereas others, mated to the same male, produce young of both sexes, several questions arise regarding the nature of such reproduction: (1) Do the unisexual strains consistently produce female offspring or does an occasional male 


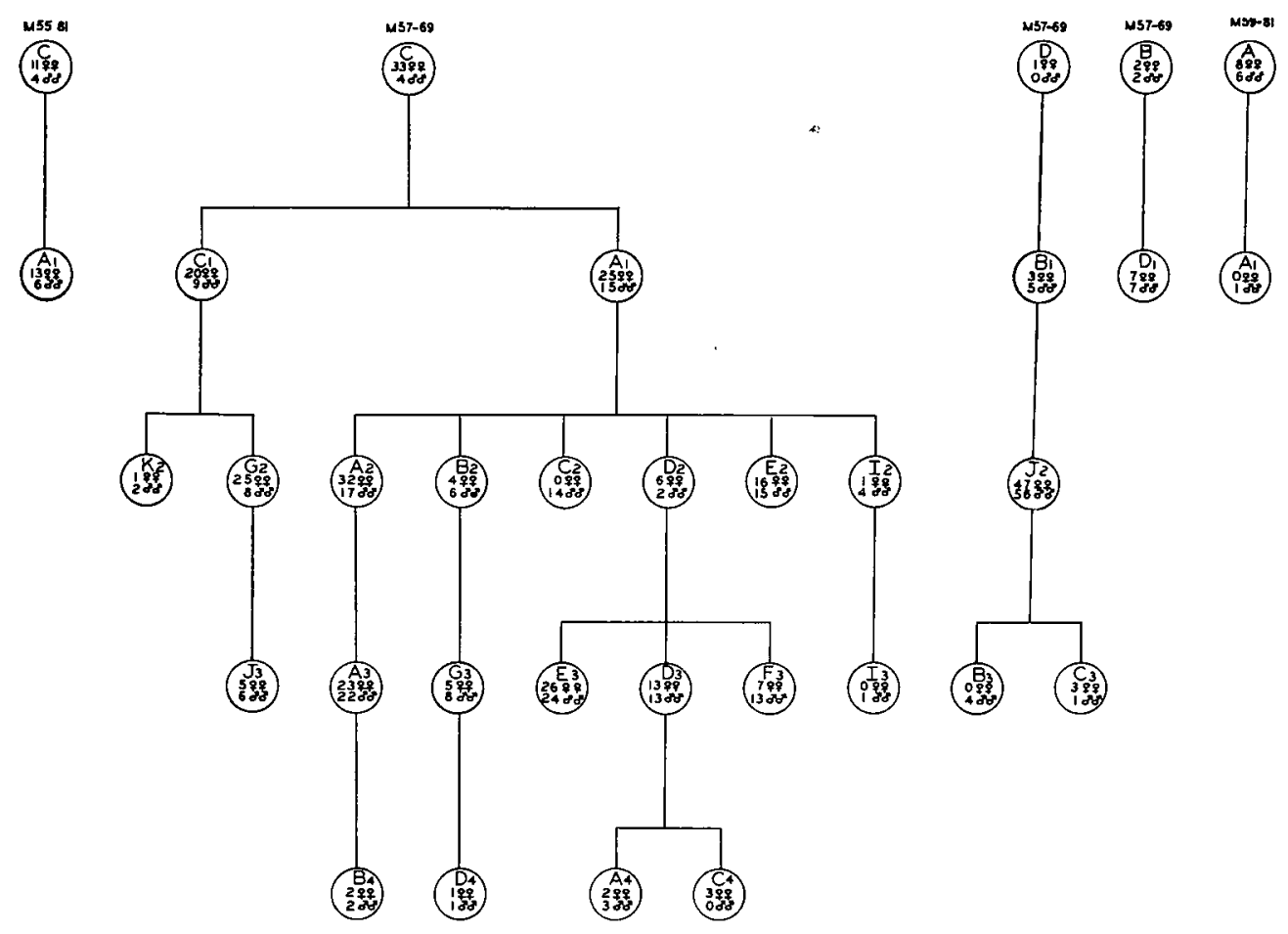

FIG. 5. Descendants of five wild "C" females. Letter $=$ female designation; subscript = laboratory generation; number $=$ offspring from each female that were raised to maturity.

result? (2) In broods from unisexual mothers, do bisexual type females ever arise? (3) Do bisexual females sometimes give birth to the unisexual type offspring? (4) What is the sex-ratio among progeny from the bisexual parents?

In an attempt to answer these questions, females of all four strains were mated and the resulting young raised to maturity. The hardiness of " $\mathrm{C}$ " and " $\mathrm{C}_{\mathbf{x}}$ " made possible the backcrossing, outcrossing, and inbreeding of various lines, but matings of " $F$ " and " $F_{x}$ " were somewhat limited by the reduced fecundity of " $F$ " under aquarium conditions.

From the live material collected in 1957 , five females proved to be of the " $\mathrm{C}_{\mathrm{x}}$ " strain. These and their descendants (fig. 4) gave birth to 923 young. After 50 died of natural causes and 276 were either discarded or preserved, 597 attained maturity; not one of these was a male. Although offspring were produced by 41 different parents, for only those " $\mathrm{C}_{\mathrm{x}}$ " females which had nine or more female offspring can randomness be discarded as a factor in the unisexuality of the progeny. From the five original " $\mathrm{C}_{\mathrm{x}}$ " females, 25 descendants fulfilled these requirements, whereas in not a single one of the $36 \quad F_{1}-F_{4}$ generations could a transfer to the bisexual type be demonstrated.

The same 1957 collection from which the "C $\mathrm{C}_{\mathrm{x}}$ " aquarium stock was derived contained three females that ultimately were shown to represent the bisexual strain. Two other females, one from the 1955 collection and one from the 1959 collection, were also of the "C" type. From these five females and their descendants, 744 young were born, some of which constituted an $F_{5}$ generation (fig. 5). The number of these offspring that reached maturity was 592 (an additional 97 died of natural causes and 55 were discarded or preserved as young). Of those that matured, 313 were 
females and 279 were males - essentially a $1: 1$ ratio (Chi-square $=1.95, P>10$ ). From the original five wild females, 28 representing the $F_{1}$ through $F_{4}$ generations were mated. All but one of these produced at least some males and, therefore, must be considered bisexual. Since from the one female only three offspring reached maturity, she cannot be considered unisexual even though no males developed. When the sexratio of offspring from each female was analyzed, it was seen that significant deviations from the expected $1: 1$ ratio occasionally occur; examples are $\mathrm{M} 57-69 \% \mathrm{G}_{2}$

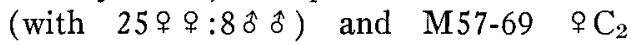
(with 0 우 $q: 14 \hat{\delta} \hat{o}$ ). A number of authors (particularly Krumholz, 1948) have indicated that among the viviparous fishes males are less hardy than are females. In explanation, Essenberg (1923) suggested that the higher metabolic rate of males is responsible. In strain " $\mathrm{C}$," although a $1: 1$ ratio was demonstrated, there is still an apparent tendency for more females to reach maturity than males. It is also possible that males are more delicate than females during the period between birth and the attainment of adulthood. Since 14.2 per cent of the offspring from " $\mathrm{C}$ " females died before they matured and only 7.7 per cent of the " $\mathrm{C}_{\mathrm{x}}$ " young died during the same period, differential mortality might account for the deviation of the $q \mathrm{G}_{2}$ progeny from a 1:1 ratio, and also cause the total number of " $\mathrm{C}$ " offspring to comprise slightly more females than males.

The exceptional sex-ratio of ${ }^{\circ} \mathrm{C}_{2}$, however, cannot be accounted for on the basis of differential mortality or chance. Since the probability of obtaining 14 male offspring by chance alone is 1 in 16,224 it might be expected that one parent or the other carried genetic factors that were strongly male-determining. The pedigree of the parents involved in this event, however, did not suggest this. A series of matings were conducted to determine whether or not this maleness was genetically transmittable, but neither by inbreeding nor backcrossing were abnormal sex-ratios again produced.

Information derived from matings of the " $F-F_{x}$ " group is similar to that of the " $\mathrm{C}-\mathrm{C}_{\mathbf{x}}$ " group. All " $\mathrm{F}_{\mathbf{x}}$ " individuals were derived from three wild females collected in 1955. These and their $11 F_{1-}$ through $\mathrm{F}_{4}$-generation female progeny gave birth to 453 young, of which 290 females were reared to maturity ( 112 were either preserved or discarded and 51 died of natural causes). As was true of " $\mathrm{C}_{x}$," not a single male was produced.

The situation in the bisexual strain, " $\mathrm{F}$," is similar to that of "C." Offspring were obtained from 17 wild females collected in 1955,1957 , and 1959. Of the 243 young born, 70 died of natural causes and 45 were discarded or preserved. The 128 that reached maturity consisted of 75 females and 53 males. Here again, as in "C," the deviation from a $1: 1$ ratio is not significant at the .05 level; yet, some differential mortality is strongly suggested.

It is now possible to answer within certain limits the questions posed earlier regarding the nature of unisexual and bisexual reproduction in Poeciliopsis. In view of the fact that no males occurred among 887 offspring of the two unisexual strains, the likelihood of such an event taking place is fairly remote. It is furthermore unlikely that females of either the bisexual or unisexual strains ever produce offspring of the other type. The sex-ratio of the bisexual strains is probably about $1: 1$ at birth, and although differential mortality results in a few more females reaching adulthood than males, the deviation from a $1: 1$ ratio is not sufficient to call for the postulation of a genetic system.

Early Gonad and Sex-Inversion.-The occurrence of unbalanced sex-ratios among cyprinodont fishes has been subject to numerous investigations. Notable among these is the work of Essenberg (1923), who showed that the preponderance of males in aquarium stocks of Xiphophorus helleri was a result of sex-inversion. Conceivably, inversion of sex could be carried suffi- 
ciently far to result in the unisexual strains of Poeciliopsis. Here, however, the inversion must be reciprocal to that of Xiphophorus, so that all individuals genetically oriented to maleness are converted to females. If such a reversal does take place, examination of gonads from a sufficient number of " $\mathrm{C}_{\mathbf{x}}$ " or " $\mathrm{F}_{\mathrm{x}}$ " young at the time that sex is first distinguishable should reveal individuals with rudiments of testes. Because " $C$ " and " $C_{x}$ " young were more readily available, they were chosen for this study. Offspring of different ages were sectioned and their gonads examined.

The gonads of Poeciliopsis " $\mathrm{C}_{\mathbf{x}}$ " young killed at birth are sexually undifferentiated. They are widely paired and are suspended beneath the swimbladder in the peritoneal sac that later becomes the permanent wall of the gland. Internally they are characterized by two cell types: (1) the small stroma cell that is indistinguishable from peritoneal cells and has an irregular, darkly staining nucleus, and (2) a series of larger cells representing the initial stages of transformation from the stroma to the primordial germ cell. In the course of this transformation, the nucleus and cytoplasm of the stroma cell increase in size, the chromatin becomes coarse and starts to clump and the once irregularly shaped nucleus rounds out, and loses its affinity for stain. Both the stroma cells and the series of transforming germ cells are evenly distributed throughout the indifferent gonad.

By the sixth day several changes have taken place and it is possible to distinguish the sexes cytologically. In females, the two halves of the ovary have begun to fuse anteriorly. The number of transforming germ cells has significantly increased, and some have more than doubled in size. The nuclei of the largest have lost their affinity for stain and, except for the strands of chromatin, are now lighter than the cytoplasm. The germ cells of the early ovary remain evenly distributed throughout the structure; but most of the stroma cells have become pressed about them in the initial formation of the follicle. By the eighth day the ovary is filled with germ cells of various sizes; the two halves of the gonad are almost completely fused and its shape has become quite irregular.

Four of the eight " $C$ " young that were sectioned were males. Three characteristics render the early testis distinct from the early ovary: (1) the germ cells are all approximately the same size, (2) most of the stroma cells are located medially, whereas the germ cells are pushed laterally, and, (3) some of the stroma cells have clustered together at the center of the testis in the formation of sperm ducts.

Having determined the differences in structure of the early testis and the early ovary, 13 " $\mathrm{C}_{\mathrm{x}}$ " females, 6 days old, were examined for evidence of maleness. The mother of these young was an $F_{1}$ female that had produced 33 other offspring, all of which matured as females. All 13 of the sectioned gonads were unmistakably female. Since the probability is 1 in 8,112 that 13 females would be selected by chance alone, it is safe to conclude that at the time sex is first established all " $\mathrm{C}_{x}$ " young are females. Hence, the premise that sex-inversion is responsible for broods of all-female offspring has no histological support. The genetic evidence, considered later, further refutes this possibility.

Cytological Results.--Chromosome numbers have thus far been determined for 27 species of cyprinodont fishes (Wickbom, 1943; Makino, 1951; and Öztan, 1954). With few exceptions the haploid number is 23 or 24 and the diploid, 46 or 48 . In all of these studies the small size of the chromosomes prevented detailed morphological analysis; consequently, little is known beyond the fact that most are rod-shaped, with terminal centromeres.

In the present study counts were made from spermatogonial divisions of strains " $C$ " and " $F$ " and from somatic tissue of the embryos of " $\mathrm{C}$," " $\mathrm{C}_{\mathrm{x}}$," and " $\mathrm{F}_{\mathrm{x}}$." The haploid number for both " $C$ " and " $F$ " males is clearly 24 (fig. 6). No deviation from this number was found in cells from approximately 12 gonads that were pre- 


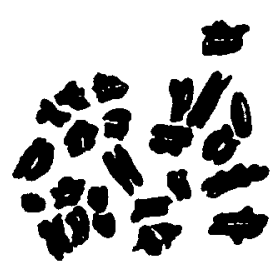

FIG. 6. First meiotic prophase (spermatogenesis), strain "C," N: 24, $1300 \mathrm{x}$.

pared for study. The diploid chromosome number determined from the somatic tissue is 48 for the bisexual and the two unisexual strains (figs. 7 and 8).

Interspecific Matings and Genetic Analysis.-In the absence of intraspecific marker genes suitable for tracing the movement of genetic material through the unisexual strains, hybrid matings of " $C$ " and " $F$ " were attempted. Both sexes of " $F$," including the " $F_{\mathrm{x}}$ " strain, have a spot on the dorsal fin (fig. 9). This aggregate of melanophores is basally located on the posterior, interradial membranes, for the most part between rays 4 and 6 . In large specimens melanophores become more numerous and in some fish cover the entire lower third of the posterior rays; at minimum development the melanin is always sufficiently concentrated to form a spot. In " $C$ " and " $\mathrm{C}_{\mathrm{x}}$ " this character is lacking (fig. 10). Although large females have a few melanophores scattered along the base of the dorsal fin, they are never concentrated into a spot.

In the first series of hybrid matings between " $\mathrm{C}-\mathrm{C}_{\mathrm{x}}$ " and " $\mathrm{F}-\mathrm{F}_{\mathrm{x}}$ " a clear-fin " $\mathrm{C}$ " female was mated to a spot-fin " $F$ " male (Hybrid Mating I, table 3). All of the off-

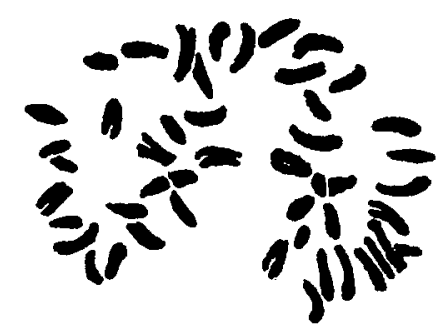

Fic. 7. Mitotic metaphase, strain "C," $2 \mathrm{~N}: 48$, $1300 \mathrm{x}$. spring had the dorsal-fin spot; but the males outnumbered the females by about 3 to 1 . When the same cross was made using the unisexual female, " $\mathrm{C}_{\mathrm{x}}$ " instead of the bisexual type (Hybrid Mating II), the fin spot was again transmitted to all of the progeny; but in keeping with the characteristic of the " $\mathrm{C}_{\mathrm{x}}$ " strain, all of the offspring were females. The cross, " $F_{\mathbf{x}}$ " $\times$ "C" (Hybrid Mating III), as expected, also produced only females, but all of these had clear fins. Hence, in the first three crosses only the phenotype of the male was transmitted to the $F_{1}$ generation. When, however, the $\mathrm{F}_{1}$ hybrid male (" $\mathrm{C}$ " $\times$ " $\mathrm{F}$ ") which had the dorsal-fin spot was mated to " $\mathrm{C}_{\mathrm{x}}$ " " $\mathrm{F}_{\mathrm{x}}$," or the $\mathrm{F}_{1}$ (" $\mathrm{F}_{\mathrm{x}}$ " $\times$ " $\mathrm{C}$ ") female, half of the offspring were spot-fin and half were clear-fin (again, no males appeared).

At this point, transmission of the dorsalfin spot would appear to be best explained by a system of sex-linkage. Although the existence of sex chromosomes has not been cytologically verified in cyprinodont fishes, the few species for which their presence has been genetically established females, with one exception, were indicated to be homogametic, XX; the males, heterogametic, XY.

When a sex-linked system with homogametic XX females was applied to the spot-fin transmission data, a fit could not be obtained, regardless of whether the spot character was considered dominant or recessive. If the female, however, were het-

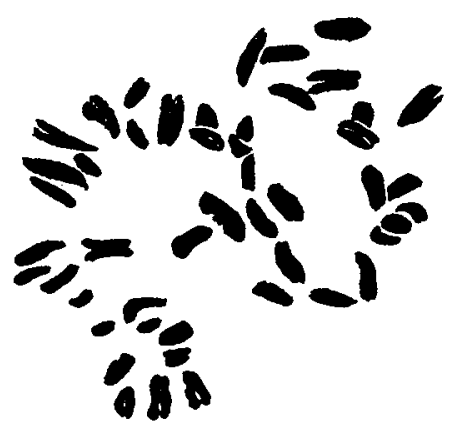

Fro. 8. Mitotic metaphase, strain " $\mathrm{C}_{\mathbf{x}}, " 2 \mathrm{~N}$ : $48,1300 \mathrm{x}$. 


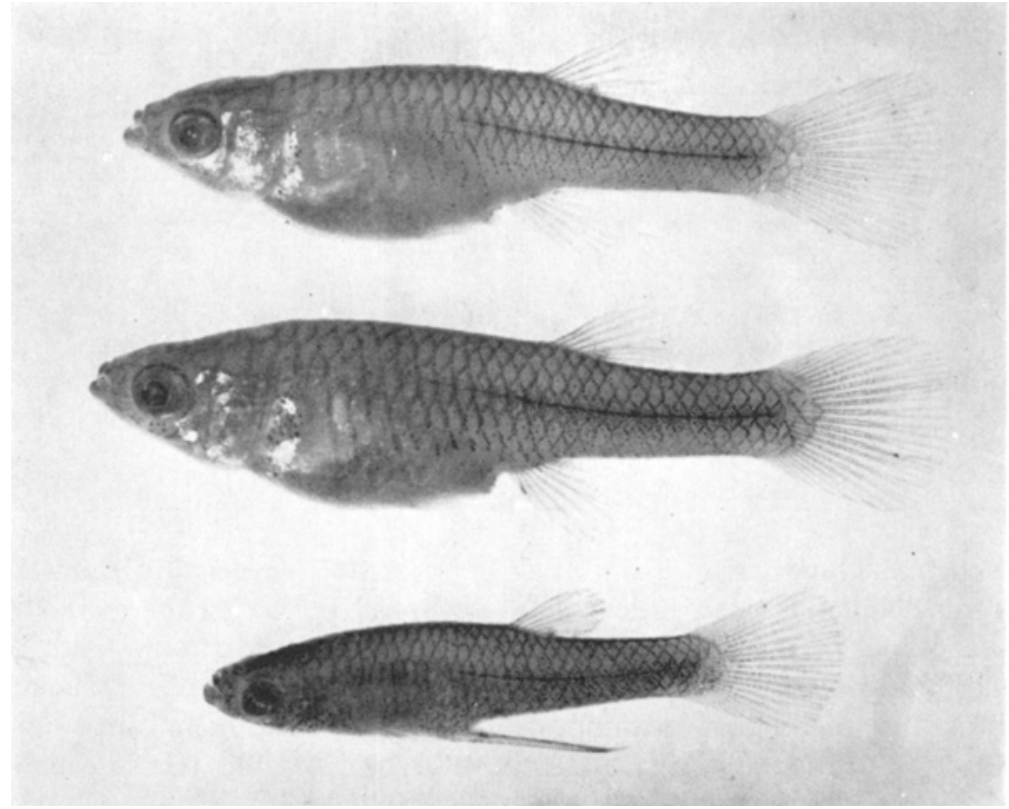

Fig. 9. Strain " $F$ " female (upper, $27.0 \mathrm{~mm}$ ), " $F_{x}$ " female (middle, $30.2 \mathrm{~mm}$ ), and " $F$ " male (lower, $22.1 \mathrm{~mm}$ ), showing dorsal-fin spot characteristic of this group.

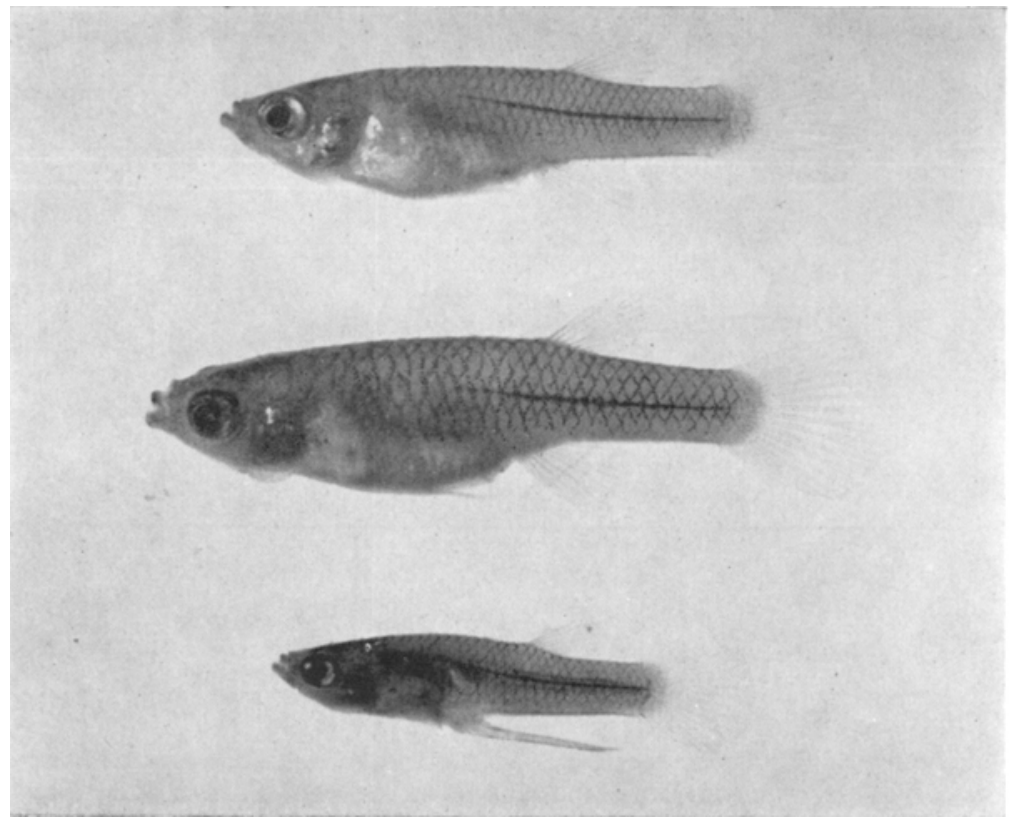

Fig. 10. Strain "C" female (upper, $22.5 \mathrm{~mm}$ ), " $\mathrm{C}_{x}$ " female (middle, $25.1 \mathrm{~mm}$ ), and "C" male (lower, $17.1 \mathrm{~mm}$ ), showing clear condition of dorsal fin of this group. 
TABLE 3. First series of hybrid matings between " $C-C_{x}$ " and " $F-F_{x}$," showing transmission of the dorsal-fin spot

\begin{tabular}{|c|c|c|c|c|c|c|}
\hline \multirow{3}{*}{$\begin{array}{l}\text { Hybrid } \\
\text { mating }\end{array}$} & \multirow{3}{*}{ Female } & \multirow{3}{*}{ Male } & \multicolumn{4}{|c|}{ Phenotype of of fspring } \\
\hline & & & \multicolumn{2}{|c|}{ Dorsal-fin spot } & \multicolumn{2}{|c|}{ No dorsal-fin spot } \\
\hline & & & Female & Male & Female & Male \\
\hline I & $\mathrm{C}$ & $\mathrm{F}$ & 21 & 57 & 0 & 0 \\
\hline II & $C_{x}$ & $\mathrm{~F}$ & 23 & 0 & 0 & 0 \\
\hline III & $F_{x}$ & $\mathrm{C}$ & 0 & 0 & 39 & 0 \\
\hline IV & $\mathrm{C}_{\mathrm{s}}$ & $(\mathrm{C} \times \mathrm{F})$ & 39 & 0 & 46 & 0 \\
\hline $\mathrm{V}$ & $F_{x}$ & $(\mathrm{C} \times \mathrm{F})$ & 4 & 0 & 2 & 0 \\
\hline VI & $\left(F_{x} \times C\right)$ & $(\mathrm{C} \times \mathrm{F})$ & 12 & 0 & 12 & 0 \\
\hline VII & $\left(F_{x} \times C\right)(C \times F)$ & $\mathrm{C}$ & 0 & 0 & 23 & 0 \\
\hline VIII & $\left(F_{x} \times C\right) \quad(C \times F)$ & $\mathrm{C}$ & 0 & 0 & 10 & 0 \\
\hline
\end{tabular}

erogametic, the male homogametic, and the dorsal-fin spot dominant to its allele, no spot, the phenotypes of the offspring from all six of the hybrid matings fulfill the requirements of the theoretical genotypes. Hybrid Matings I, III, and VI (fig. 11) show the genotype and phenotype of the

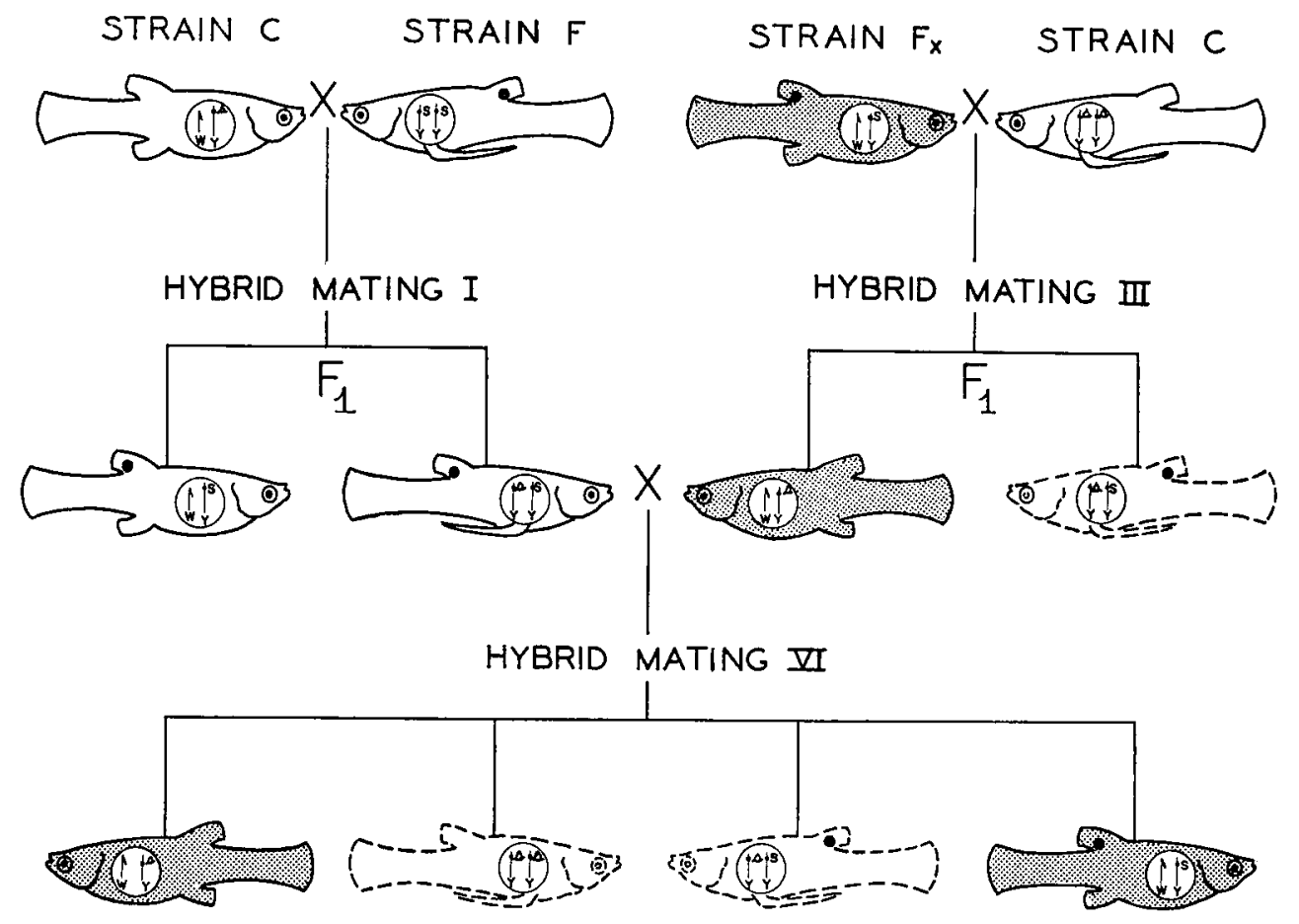

FIG. 11. Inheritance of dorsal-fin spot in hybrid crosses between strains " $\mathrm{C}-\mathrm{C}_{\mathbf{x}}$ " and " $\mathrm{F}-\mathrm{F}_{\mathbf{x}}$," assuming females to be heterogametic (WY) and males homogametic (YY) and the spot-fin character to be dominant (S). Unisexual strains are indicated by stippling; males by presence of gonopodium. Had males been born to unisexual females, their genotypes and phenotypes would have been as represented in broken-line figures. parents and progeny in terms of this hypothesis. Following the method of Gordon (1952), the sex chromosomes of the heterogametic female are designated "WY" and those of the homogametic male "YY." In Hybrid Mating III, in which a spot-fin " $F_{\mathbf{x}}$ " female, $\mathrm{W}^{-} \mathrm{Y}^{\mathrm{S}}$, was mated to a clear- 
fin " $\mathrm{C}$ " male, $\mathrm{Y}^{\mathrm{s}} \mathrm{Y}^{\mathrm{s}}$, all offspring were clear-fin females. Under normal circumstances, males should be heterozygous $\mathrm{Y}^{\mathrm{S}} \mathrm{Y}^{\mathrm{s}}$ and have the fin spot. Since males are not produced by unisexual females, however, no spot-fin progeny occurred-leaving only the $W^{-} Y^{s}$ genotype. When these $W^{-} Y^{s}$ $\mathrm{F}_{1}$ hybrid females were mated to the $\mathrm{Y}^{\mathrm{s}} \mathrm{Y}^{\mathrm{s}}$ heterozygous male (Hybrid Mating VI), half of the progeny were spot-fin females and half were clear-fin females and hence were $\mathrm{W}^{-} \mathrm{Y}^{\mathrm{s}}$ and $\mathrm{W}^{-} \mathrm{Y}^{\mathrm{s}}$, respectively. If males had been produced here their genotypes, $Y^{s} Y^{s}$ and $Y^{s} Y^{s}$, would have resulted in half of them having the spot and half having no spot. The two types of $\mathrm{F}_{2}$ females produced by this cross are the same genotype as " $\mathrm{C}_{\mathrm{x}}$ " $(\mathrm{W}-\mathrm{Y})$ and " $\mathrm{F}_{\mathrm{x}}$ " $\left(W^{-} Y^{s}\right)$. It, therefore, follows that mating these females to " $\mathrm{C}$ " males ( $\mathrm{Y}^{\mathrm{s}} \mathrm{Y}^{\mathrm{s}}$ ) should result in the same type of offspring as would be obtained by mating " $\mathrm{C}_{\mathrm{x}}$ " or " $\mathrm{F}_{\mathrm{x}}$ " females to " $\mathrm{C}$ " males, that is, all clear-fin females. The progeny from both of these crosses $\left(\mathrm{W}^{-} \mathrm{Y}^{\mathrm{s}} \times \mathrm{Y}^{\mathrm{s}} \mathrm{Y}^{\mathrm{s}}\right.$ and $W^{-} Y^{s} \times Y^{s} Y^{s}$ ), in Hybrid Matings VII and VIII, were, as predicted, all clearfin females (table 3 ).

In the " $F_{x}$ " $X$ " $C$ " cross, had a bisexual " $F$ " female been used instead of the unisexual strain, progeny of both sexes would have resulted. The $F_{1}$ males produced, unlike their clear-fin, $W^{-} Y^{s}$ sisters, would be heterozygous $\mathrm{Y}^{\mathrm{s}} \mathrm{Y}^{\mathrm{s}}$ for the dorsal-fin spot. It was not until 1959, however, after a new stock of " $F$ " was available, that this cross was successfully completed. The 13 offspring that resulted consisted of eight females and two males, but instead of all $F_{1}$ females being clear-fin $\left(W-Y^{s}\right)$ and all males spot-fin $\left(\mathrm{Y}^{\mathrm{S}} \mathrm{Y}^{\mathrm{s}}\right)$, as the sex-linked hypothesis demands, both sexes had the dorsal-fin spot.

In Hybrid Mating XII, in which an $\mathrm{F}_{1}$ hybrid female ("C" $\times$ " $F$ ") was mated to the clear-fin " $\mathrm{C}$ " male, the $\mathrm{W}-\mathrm{Y}$ ( clear $\%$ ), genotypes predicted by the sex-linked hypothesis again were not obtained. Instead of the females being clear-fin and the males spot-fin, a 1:1:1:1 ratio was ob- tained, suggesting, rather than sex-linkage, a simple Mendelian type of inheritance. In this hybrid experiment the spot character in most of the offspring was less developed than in the original " $F$ " parent. Although individuals of the " $F-F_{x}$ " group vary somewhat in the degree to which the dorsal-fin spot is expressed, critical examination of the $F_{1}$ progeny from " $C$ " $\times$ " $F$ " and the reciprocal cross left little doubt that the character is actually intermediate when hybrid matings involve bisexual females. This type of inheritance is in keeping with what is known of other fish hybrids, wherein the $F_{1}$ generations are almost exclusively intermediate between the parental species. In most of these hybrids, however, expression of species characters is controlled or influenced by multiple factors, such that in backcrossing to the original parents introgression is a gradual process. Expression of the dorsal-fin spot, however, does not depend on the cumulative effect of a number of genes. Apparently only one allele is involved and the heterozygous condition results in incomplete dominance, such that for either sex: (1) SS = strongspot, (2) Ss = weak-spot, and (3) ss = no spot. In the backcrosses, then, "C" $\times($ " $C$ " $\times$ "F") becomes ss $\times$ Ss, which produced both male and female offspring, half of each with clear-fins, ss, and half with a weak-spot, Ss; ("C" $\times$ "F") $\times$ "C" becomes Ss $X$ ss which again results in half clear-fin and half spot-fin progeny, whereas ("C" $\times$ "F") $\times$ " $F$ " becomes Ss $\times$ SS, from which only spot-fin young are derived, but of two types: Ss, weak-spot, and SS, strong-spot.

" $C$ " and " $F$ " males and females, consequently, have chromosomes with homologous loci, which act on the same character, but with opposite effect. In the unisexual strains the corresponding locus is not found on the chromosome designated as " $W$ " in fig. 11. The s-gene carried by either gamete of the "F" male is therefore allowed full expression in combination with the W-chromosome. Fertilization by either gamete of the "C" male, however, in com- 
TABIE 4. Second series of hybrid matings between " $C-C_{x}$ " and " $F-F_{x}$ " showing transmission of fin-spot character

\begin{tabular}{|c|c|c|c|c|c|c|}
\hline \multirow{3}{*}{$\begin{array}{l}\text { Hybrid } \\
\text { mating }\end{array}$} & \multirow{3}{*}{ Female } & \multirow{3}{*}{ Male } & \multicolumn{4}{|c|}{ Phenotype of of fspring } \\
\hline & & & \multicolumn{2}{|c|}{ Dorsal-fin spot } & \multicolumn{2}{|c|}{ No dorsal-fin spot } \\
\hline & & & Female & Male & Female & Male \\
\hline IX & $\mathbf{F}$ & $\mathrm{C}$ & 11 & 3 & 0 & 0 \\
\hline $\mathrm{X}$ & $\mathrm{C}$ & $(\mathrm{C} \times \mathrm{F})$ & 23 & 20 & 25 & 35 \\
\hline $\mathrm{XI}$ & $(\mathrm{C} \times \mathrm{F})$ & $\mathrm{F}$ & 4 & 23 & 0 & 0 \\
\hline XII & $(\mathrm{C} \times \mathrm{F})$ & $\mathrm{C}$ & 4 & 3 & 6 & 4 \\
\hline XIII & $(F \times C)$ & $\mathrm{C}$ & 8 & 1 & 3 & 3 \\
\hline XIV & $(\mathrm{C} \times \mathrm{F})$ & $(\mathrm{C} \times \mathrm{F})$ & 12 & 13 & 1 & 5 \\
\hline
\end{tabular}

bination with the $\mathrm{W}$-chromosome, results in only the clear-fin condition. If males were produced from " $F_{x}$ " $\times$ " $C$," the spot would then be present only in an intermediate form, since the $F_{1}$ male would contain an S-gene from the " $F_{x}$ " female and an s-allele from the " $\mathrm{C}$ " male. In Hybrid Matings IV, V, and VI, wherein " $\mathrm{C}_{x}$, " " $F_{x}$ " " and $F_{1}$ hybrid (" $F_{x} " \times$ " $C$ ") females were mated to the $F_{1}$ hybrid male ("C" $\times$ " $F ")$, the two types of male gametes, one marked by the S-gene and one by the s-allele, combined with the female gamete containing the $W$-chromosome to produce half spot-fin and half clear-fin daughters. If expression of the spot-fin character were controlled by multiple factors involving even as few as two loci, four types of gametes would be produced by the $F_{1}$ hybrid male: $A B, A b, a B$, and $a b$. The first three of these combined with the $\mathrm{W}$-chromosome would result in spot-fin females, whereas only the latter would produce clear-fin individuals. Since the ratio of spot-fin to clear-fin progeny in all three crosses was $1: 1$ and not $3: 1$, it is safe to conclude that multiple factors are not involved.

The phenotypes of only one of the 14 crosses (tables 3 and 4 ) do not conform to the expected ratio. When the $F_{1}$ offspring of " $\mathrm{C}$ " $\times$ " $\mathrm{F}$ " were inbred in $\mathrm{Hy}$ brid Mating XIV, a 3:1 ratio was expected. All but six of the 31 offspring, however, had either a weak or a well-developed spot. The phenotypic ratio in this cross evidently was altered by the deleterious effects of hybridization. Brood size data and em- bryological data indicated that 50 to 80 per cent of the would-be $F_{2}$ progeny were stillborn.

A prominent feature in several of the hybrid matings involving females of the bisexual strains is the discrepancy from a 1:1 sex-ratio. This is particularly noticeable in the " $C$ " $X$ " $F$ " and (" $C$ " $\times$ " $F ")$ $\times$ " $F$ " matings, in which $1: 3$ and $1: 5$ ratios favored the males. In others, such as " $\mathrm{F}$ " $\times$ " $\mathrm{C}$ " and ("F" $\times$ " $\mathrm{C}$ ") $\times$ " $\mathrm{C}$," the ratio is apparently reversed, with two or three times as many females as males. Differential mortality is probably negligible, since broods sometimes contained as many as 10 young.

One female of Hybrid Mating I (" $\mathrm{C}$ " $\times$ " $F$ "), that produced 39 female and 16 male offspring (all of which had the dorsal-fin spot), was remated to a male of her own species after the " $F$ " sperm was exhausted. In the new combination she produced $47 \mathrm{fe}$ males and 56 males (all of which lacked the dorsal-fin spot), thus restoring the $1: 1$ sex-ratio. In view of this result and the evidence against a lethal mechanism, it seems likely that the sex-determining factors of " $C$ " and " $F$ " have a difference in potential. This matter is further pursued in the discussion of sex-determination in both the unisexual and bisexual forms.

\section{Discussion}

Sufficient biological and experimental evidence is now available to permit an evaluation of the Poeciliopsis problem in terms of what is known of one-sided sex-inheritance in other animals. Since the literature 
treating this subject is too extensive for a complete review, only a few examples of the various reproductive processes are presented.

\section{Parthenogenesis and Gynogenesis}

Parthenogenesis is a common phenomenon in the animal kingdom; one form or another has been found in nearly all of the major phyla. Beatty (1957), White (1954), and Suomalainen (1950) have discussed at length the various types of parthenogenesis and have indicated that nowhere among the vertebrates has a species or strain been found that normally reproduces without fertilization. Although numerous examples may be cited in which cell division was initiated in fish, amphibian, and mammalian eggs by physical or chemical stimulation, most of the artificially produced individuals failed as early embryos. Only the Beltsville Small White turkey has produced viable progeny from unfertilized and apparently unstimulated eggs (Olsen and Marsden, 1954 and Kosin, Sato, and Nagra, 1958). All of these parthenogenetic birds were males, some of which reached maturity and yielded small amounts of semen containing motile spermatozoa (Poole, 1959).

Among the teleost fishes a few special cases are known. These involved virgin births from two females of Lebistes reticulatus and from one female of Xiphophorus helleri (Stolk, 1958). The ovaries of each female were found to be infested with the phycomycete Ichthyophorus hoferi PlehnMulsow, which apparently provided a toxic substance responsible for the artificial stimulation of the ova. More than 64 offspring were produced by this pathological parthenogenetic process; these, without exception, were females.

The famous Mollienesia formosa, mentioned early in this paper, was studied for 12 years by Hubbs and Hubbs (1932, 1946) and Hubbs (1955) during which time 21 generations of over 8,000 offspring were produced, all of which were phenocopies of the female parent. Isolated $M$. formosa virgins produced no young; but when placed with males of $M$. latipinna or $M$. sphenops (species with which $M$. formosa is sympatric) large broods resulted. It was concluded that Mollienesia formosa reproduces by a process of gynogenesis, wherein sperm is essential to initiate development of the embryo but does not actually take part in formation of the zygote.

A similar situation has since been reported (Lieder, 1955) wherein certain populations of goldfish (Carassius auratus) specified as the silver goldfish (C. $a$. gibelio) produced only female progeny. Here again stimulus to the ova was provided by other species, in this case a goldfish and a carp.

The evidence that parthenogenetic or gynogenetic reproduction occurs in fishes, and that three of the four species for which it has been postulated belong to the same family as Poeciliopsis, suggests that a similar mode of reproduction might be functional in this genus. In order for either process to provide a suitable explanation for the production of only female of fspring it is essential that no paternal characters appear in any of the progeny and that the sperm serve no purpose beyond that of a stimulating agent. Although intraspecific marker genes, suitable for testing such a hypothesis are not known for " $C$ " and " $F$," interspecific matings involving the transmission of the dorsal-fin spot have provided the necessary character. In Hybrid Mating II (table 3) it was demonstrated that a clear-fin " $\mathrm{C}_{\mathrm{x}}$ " female mated to a spot-fin " $F$ " male resulted in 23 female progeny, all of which had the spot. Crossing a spot-fin " $F_{x}$ " female in Hybrid Mating III with a clear-fin male gave 37 offspring, all with the pigment condition of the male. The consistent expression of paternal characters by unisexual progeny in these and other hybrid experiments (table 3 ) is conclusive evidence that parthenogenesis or gynogenesis cannot explain the all-femaleness of Poeciliopsis strains " $\mathrm{C}_{\mathrm{x}}$ " and " $F_{x}$." 


\section{Lethal Mechanism}

Abnormal sex-ratios resulting from differential viability have been reported numerous times. Most of these, however, do not result in complete annihilation of one sex. The hybrid cross of Drosophila melanogaster $\times D$. similans is exceptional and more closely resembles the situation in Poeciliopsis, in that only females are present among the mature offspring. Sturtevant (1920) found that most of the dead and dying larvae of the cross are males. A similar mechanism is known in Drosophila prosaltens (Cavalcanti, Falcão, and Castro, 1957). In this species, as in the two species of Poeciliopsis, both unisexual and bisexual strains of females are known. Although normal $D$. prosaltens mothers, like those of Poeciliopsis strains " $\mathrm{C}$ " and " $\mathrm{F}$," produced no daughters of the unisexual types, the unisexual flies differed from " $\mathrm{C}_{\mathrm{x}}$ " and " $\mathrm{F}_{\mathrm{x}}$ " by occasionally giving rise to the bisexual form. It was believed by the above authors that the unisexual type females carry a cytoplasmic factor $\mathrm{O}$ (omikron), which is reproduced only in those individuals homozygous or heterozygous for the "sex-ratio" gene, $S_{r}$. The omikron plasmagene, which is transmitted exclusively through the eggs of "sex-ratio" females, kills only the XY embryos.

It is not inconceivable that a similar lethal system is responsible in Poeciliopsis for the lack of male offspring from strains " $\mathrm{C}_{\mathrm{x}}$ " and " $\mathrm{F}_{\mathrm{x}}$." Transmission of the character of the dorsal-fin spot is not contradictory to such a mechanism. In Hybrid Mating III (fig. 11), in which " $F_{x}$ " was mated to "C," the $\mathrm{Y}^{\mathrm{s}} \mathrm{Y}^{\mathrm{s}}$ genotype of the males was not represented among the $\mathrm{F}_{1}$ progeny; only clear-fin, $\mathrm{W}^{-} \mathrm{Y}^{\mathrm{s}}$, females were produced. In the same cross but with normal females, the $\mathrm{Y}^{\mathrm{s}} \mathrm{Y}^{\mathrm{s}}$ genotype was expressed by the $F_{1}$ males as a dorsal-fin spot of intermediate intensity.

In spite of the attractiveness of a lethalmechanism explanation of unisexuality in Poeciliopsis, biological evidence offers no support. A lethal gene in poeciliids might produce its effect during either a prenatal or postnatal stage, at either of which it would be readily detectable. The percentages of deaths among offspring from the four strains of females were as follows: " $\mathrm{C}_{\mathrm{x}}$," 7.7\%; "C," 14.2\%; " $\mathrm{F}_{\mathrm{x}}$," 15.0\%; and " $F$," 35.4\%. From " $\mathrm{C}_{\mathrm{x}}$ " females, entire broods of 20 and 34 offspring were raised to adulthood without a single loss. Since so few deaths occur among the progeny of the unisexual strains, a lethal mechanism is unsubstantiated for the period between birth and sexual differentiation.

It is still possible, however, for the expression of a lethal gene to be limited to the prenatal stage. One would expect under such circumstances to find brood sizes of unisexual females reduced to about half those of the bisexual strains, but no such reduction was found. The brood size of each unisexual strain was about equal to that of its bisexual counterpart (figs. 2 and 3). "C" females in the smaller size ranges produced slightly more young than " $\mathrm{C}_{\mathrm{x}}$ " females, but larger " $\mathrm{C}_{\mathrm{x}}$ " females had broods that were twice the size of those of any other species of Poeciliopsis. Furthermore, dissected ovaries of " $\mathrm{C}_{\mathrm{x}}$ " females contained rarely more than one degenerating embryo, even when as many as 30 healthy ones were developing. The hypothesis that unisexuality is a result of a lethal system acting during either the prenatal or postnatal period must, therefore, be rejected.

\section{Sex-Inversion}

Sex-inversions have been found in a variety of animals, but the incidence is strongest in those with sex-determining mechanisms still in a primitive state (White, 1954). Cyprinodont fishes fall into this category. Their sex-chromosomes are so little differentiated as to be morphologically indistinguishable from autosomes. The sex of animals of this type is often unstable, and subject to alteration by both internal and external factors.

Among the cyprinodont fishes examples of sex-inversion are known. For example, in the guppy, Lebistes reticulatus, and the medaka, Oryzias latipes, the normal XX 
(ㅇ) $-\mathrm{XY}(\hat{\delta})$ relationship is occasionally upset by an imbalance of minor sex-determining genes on the autosomes (Winge and Ditlevsen, 1947; Aida, 1936). Matings of these reversed $\mathrm{XY}$ females and $\mathrm{XX}$ males to normal individuals resulted in progeny with extremely abnormal sex-ratios. In the swordtail, Xiphophorus helleri, unusual sex-ratios have been attributed to sex-determining systems relying on hormonal control (Essenberg, 1923 and Friez, 1933).

Kosswig (1954) presented a generalized theory of sex-determination for fishes in which he stressed both environmental and genetic factors.

The evidence that sex-inversions do occur in cyprinodonts suggests that one such system might be functioning in Poeciliopsis strains " $\mathrm{C}_{\mathrm{x}}$ " and " $\mathrm{F}_{\mathrm{x}}$." External, internal, genetic, and cytoplasmic influences have all been considered.

In rearing viviparous fishes, standardization of the external environment is impractical; consequently, offspring from each of the four strains of females were reared under all available aquarium conditions. Regardless of the light, temperature, time of year, space, food, or any other physical variable in the laboratory, females of the bisexual strains produced both male and female progeny and females of the unisexual strains produced only female young.

If sex-reversal is to be considered a characteristic of " $\mathrm{C}_{\mathrm{x}}$ " and " $\mathrm{F}_{\mathrm{x}}$," it is more likely to be operative through an internal process. Histological evidence, presented above, is strongly contradictory to the concept of an inversion brought about by endocrine imbalance. Sectioned gonads from " $\mathrm{C}_{\mathrm{x}}$ " young killed at the time of sexual differentiation revealed no evidence of male origin. This, however, does not exclude some autosomal or cytoplasmic control that may gain prominence over the sex-chromosomes prior to the formation of a distinct gonad. It is in the transmission data of the dorsal-fin spot that evidence contradicts sex-inversion in any form.
In Hybrid Mating III (fig. 2), a spotfin " $F_{x}$ " female was mated to a clear-fin "C" male. Since the gene for spot-fin is located on only one " $F_{x}$ " chromosome, two types of gametes should normally occur. One of these, which is marked by a chromosome lacking the spot-gene locus, when combined with either of the clear-fin male gametes results in clear-fin females. The other female gamete, marked by the spotfin gene, should in combination with the clear-fin male gametes result in male offspring in which the spot-fin is expressed with reduced intensity. If these spot-fin males were genetically produced but reversed to females, half of the offspring of the " $F_{x}$ " $\times$ " $C$ " cross would have a spot on the dorsal fin. It can, therefore, be concluded that autosomal or cytoplasmic factors or hormonal or physical influences do not reverse the sex of " $\mathrm{C}_{\mathrm{x}}$ " or " $\mathrm{F}_{\mathrm{x}}$ " males to females.

\section{Incompatibility Mechanisms}

In a number of plants, for example $Z e a$, Datura, and Oenothera, incompatibility systems that have arisen between the style and pollen grains cause differential pollentube growth. Since one pollen tube may grow slower than the other, incompletely, or not at all, only one type of gamete may reach the ovary.

In viviparous fishes a similar relationship might exist between the gonaduct and the spermatozoa, whereby viability or motility of the sperm is adversely affected. If the male gametes are of two types, one carrying the female-determining factors and the other male determiners, failure of the latter to reach the ova could result in only female progeny.

Hybrid matings between " $\mathrm{C}-\mathrm{C}_{\mathbf{x}}$ " and " $\mathrm{F}-\mathrm{F}_{\mathrm{x}}$," however, demonstrate the unlikelihood of such a system operating within the unisexual strains (table 3). Gametes of the "C" $\times$ " $F$ " $F_{1}$ male were marked by either the clear-fin gene, $s$, or the spotfin gene, S. When, in Hybrid Mating IV, a clear-fin " $\mathrm{C}_{\mathbf{x}}$ " female was mated to this male, both phenotypes were represented 
among the female progeny in a $1: 1$ ratio, thus demonstrating that each gamete was equally effective in fertilizing ova.

\section{Polyploidy}

Although polyploidy has been a significant factor in the evolution of plants, it has played a minor role in the animal kingdom. The fact that most animals with reduplicated sets of chromosomes or increases of one or more elements are either parthenogenetic or hermaphroditic strongly suggests that bisexual reproduction acts as a barrier to polyploidy (Muller, 1925). The claim of Svärdson (1945) and Kupka (1948) that polyploidy has occurred in salmonid fishes is based on conflicting evidence and is not widely accepted. Among the vertebrates a single triploid newt, Triturus vulgaris, is the only known naturally occurring example (Böök, 1940). Experimentally produced triploid and tetraploid Amphibia are not uncommon, but they invariably are sterile; consequently, it is quite unlikely that polyploidy has played a part in the evolution of Amphibia (White, 1954).

In fishes, although an exclusively female $F_{1}$ generation might be produced by an increased dosage of female determiners through polyploidy, the problem of sterility remains. Were this not so, there would still be no reason to believe that the second generation would also be all-female since segregation should result in some gametes with the normal haploid chromosome number. Inasmuch as the unisexual strains of Poeciliopsis have failed to give rise to a single male in five generations, it seems unlikely that polyploidy or aneuploidy is involved. Furthermore, the cytological evidence is completely negative. The haploid chromosome number of " $\mathrm{C}$ " and " $\mathrm{F}$ " males, which serve as mates to both the unisexual and the bisexual strains, is invariably 24 . Embryos obtained from " $\mathrm{C}_{\mathrm{x}}$ " and " $F_{\mathbf{x}}$ " females have the diploid number 48 , which is the same as that of embryos from the bisexual strain, "C." Polyploidy can, therefore, be excluded from the list of mechanisms that might be responsible for the unisexual strains of Poeciliopsis.

\section{Conclusions}

Results obtained from studying the reproductive biology of Poeciliopsis strains " $\mathrm{C}_{\mathrm{x}}$ " and " $\mathrm{F}_{\mathrm{x}}$ " reduce considerably the number of possible explanations for their unisexuality. Inheritance of the dorsal-fin spot contributed most to the final conclusion. In hybrid crosses between the bisexual types, "C" and " $F$," the spot-fin condition is determined by a pair of alleles such that in " $F$," SS resulted in the finspot; in "C," ss resulted in no spot; and in the $F_{1}$ hybrid progeny, Ss showed incomplete dominance with the spot character present in dilute form. When hybrid matings involved either of the unisexual strains, the pattern of inheritance differed. Invariably the fin condition of the male was transmitted unaltered to the $F_{1}$ progeny. If a hybrid male (Ss) was the father, two phenotypes were represented, strong spot and no spot in a 1:1 ratio, with the intermediate condition absent.

It was concluded from a series of hybrid matings using all four strains with " $\mathrm{C}$ " and "F" males that the unisexual strains differ from the males and females of the bisexual strains by at least one chromosome. This nonhomologous chromosome, which for convenience was labelled " $W$," has no effect on the dorsal-fin spot. In the unisexual progeny expression of fin pigment depends on the paternal chromosome, "Y," which carries the gene-S for fin-spot or its allele-s for no spot. Either of these genes combined with the " $W$ " chromosome is allowed full expression, but when paired with each other in the bisexual strains the opposing effect results in dilution.

When an " $F_{\mathrm{x}}$ " $\left(W^{-} Y^{s}\right)$ female is crossed with a "C" ( $\left.\mathrm{Y}^{\mathrm{s}} \mathrm{Y}^{\mathrm{s}}\right)$ male, clear-fin, $\mathrm{W}^{-} \mathrm{Y}^{\mathrm{s}}$, hybrid females are produced, but the $Y^{\mathrm{s}} \mathrm{Y}^{\mathrm{s}}$ weak-spot individuals are not represented among the progeny as either males or females. The same phenomenon occurs in the "C $\mathrm{C}_{\mathrm{x}}$ " $\left(\mathrm{W}-\mathrm{Y}^{\mathrm{s}}\right) \times$ " $\mathrm{F}$ " $\left(\mathrm{Y}^{\mathrm{s}} \mathrm{Y}^{\mathrm{s}}\right)$ cross. Only $\mathrm{W}^{-} \mathrm{Y}^{\mathrm{s}}$, strong-spot, females are obtained 
and the $\mathrm{Y}^{\mathrm{S}} \mathrm{Y}^{\mathrm{s}}$ genotype is again lost. In these and other crosses it was noted that, regardless of whether the gametes provided by the male carried the S-gene or its sallele, transmission occurred, yet in the unisexual females, only the $\mathrm{W}$-type gamete was transmitted. If the fate of the paternal chromosome can be determined, unisexuality in " $\mathrm{C}_{\mathrm{x}}$ " and " $\mathrm{F}_{\mathrm{x}}$ " will be explained.

The possibility that all YY males produced by unisexual females die prior to maturity was rejected on the basis of the low prenatal and postnatal mortality; hence loss of the Y-chromosome takes place before fertilization. An almost complete lack of degenerating ova within " $\mathrm{C}_{\mathrm{x}}$ " and " $\mathrm{F}_{\mathrm{x}}$ " ovaries, excluded the possibility that the Y-bearing gametes died. It must, therefore, be concluded that only the W-type egg is produced and that the $\mathrm{Y}$-chromosome is lost during oogenesis. In each generation, then, only the W-bearing ovum combines with the $\mathrm{Y}$-bearing sperm to produce a WY female.

Although transmission data from the hybrid crosses with the unisexual females indicates a WY-chromosome system, this designation is unjustifiable in terms of the bisexual hybridization data, in which the marked chromosomes segregated randomly and behaved as autosomes. In Hybrid Mating XII, when an $F_{1}$ hybrid (" $C$ " $\times$ "F") female was backcrossed to the clearfin " $C$ " male, all of the female progeny should have been $\mathrm{W}^{\mathrm{s}} \mathrm{Y}^{\mathrm{s}}$ and, hence, clearfin, whereas all of the males, $\mathrm{Y}^{\mathrm{S}} \mathrm{Y}^{\mathrm{s}}$, should have had the dilute spot (table 4). Since both spot-fin and clear-fin males and spotfin and clear-fin females were produced in a $1: 1: 1: 1$ ratio, it is questionable whether the marked chromosomes are by themselves responsible for sex-determination. Consequently, there is no reason to consider the chromosomes with the spot-fin locus as sexchromosomes. In fact there is evidence that sex-determination in " $C$ " and " $F$ " is in part, if not completely, dependent on genes dispersed among the autosomes. It is shown above that progeny from certain hybrid crosses have unbalanced sex-ratios, and it is suggested above that the sexdetermining potential differs among the various species of Poeciliopsis. In the group with which we are here concerned sex-determining factors in " $F$ " males and females are stronger than those of "C." Although these sex-determiners are balanced in intraspecific matings, the balance is not maintained in hybrid crosses. Consequently, when " $C$ " females are mated to " $F$ " males the stronger male-producing genes of " $F$ " combine with the weaker female-producing genes of " $C$ " to result in a sex-ratio of 1 우:3영 (table 3). Excessive mortality was not a feature of this experiment. In the reciprocal cross (" $F$ " $\times$ " $C$ ") stronger female-determining factors combined with the weaker male determiners, and the ratio was shifted in the opposite direction. Maturation division within the $F_{1}$ hybrids results in a mixing of the strong and weak elements, promoting an intermediate condition. The gametes of the " $C$ " $\times$ " $F$ " hybrid males, therefore, are not as strongly male-determining as those of " $\mathrm{F}$," yet their potential exceeds that of "C." When such a male is backcrossed to a " $\mathrm{C}$ " female, male offspring still slightly outnumber the females, but not significantly so, since differential mortality tends to equalize the ratio. In the " $C$ " $\times$ " $F$ " hybrid female, the same mixing of sex-determiners takes place, to result in ova that tend toward maleness. Combining these gametes with strong male-determining gametes of " $F$ " results in nearly all male progeny: only 4 out of 27 were females (table 4).

Hybrid crosses involving members of the genus Poeciliopsis, not considered in this study, suggest that a similar situation exists for other closely related species. In some the difference in potential of sex factors is greater than in " $C$ " $\times$ " $F$," whereas in others it is less defined.

This relationship of strong and weak sexdeterminers bears some resemblance to the genetic mechanism in the gypsy moth, Lymantria dispar. In this species the maleand female-determining factors are in equilibrium in pure-bred races, but in in- 
terracial crosses involving "weak" females and "strong" males the $F_{1}$ generation is completely male in appearance (Goldschmidt, 1931, 1932, 1934). Half of these, however, proved to be intersexes. In $L y$ mantria, females are heterogametic, so that the $\mathrm{X}$ - (or Z-) chromosome is male-determining and variable in potency, but the female-determining factors evidently are cytoplasmic.

Although interracial crosses of Lymantria dispar and interspecific crosses of Poeciliopsis are comparable on the basis of varying degrees of sex-determining potential, here the similarity ends. In Lymantria the ratio of males to females is not really shifted but intersexes take the place of what normally would constitute one of the sexes. Furthermore, in $F_{1}$ hybrids of Poeciliopsis the sexdetermining factors are redistributed in such a way that equilibrium is eventually restored, as would be true with polygenic inheritance.

If in the bisexual strains, sex is determined totally or in part by a number of genes dispersed among the autosomes, the hypothesis that femaleness in " $\mathrm{C}_{\mathbf{x}}$ " and " $F_{x}$ " is attributable to a single chromosome referred to as "W" is open to question. It is a more reasonable assumption that sex here is also controlled by a number of genes. Since chromosomes carrying these genes do not undergo random assortment during oogenesis, but behave as a unit, interpretation of the data is the same as though a single nonhomologous sex-chromosome were involved. Genes carried by this unit are responsible for such differences between the bisexual and unisexual strains as: dentition, ova size, size of young at birth, maximum size of adults, age and size at maturity, etc.

It is probable that in the recent past a species of Poeciliopsis, not closely related to "C" or " $\mathrm{F}$," through hybridization altered the genomes of the strains now known as " $\mathrm{C}_{\mathbf{x}}$ " and " $\mathrm{F}_{\mathrm{x}}$." Some of the foreign chromosomes were retained by the unisexual strains in subsequent backcrosses. These chromosomes not only carry genes responsible for the modified characters noted above but also have female-determining factors too strong to be counterbalanced by the male determiners on the corresponding chromosomes. In hybrid combinations between closely related species of Poeciliopsis, such as "C" and "F," the high degree of genic compatibility permits normal pairing and segregation of chromosomes during meiosis. The "new" chromosomes contained by " $\mathrm{C}_{\mathrm{x}}$ " and " $\mathrm{F}_{\mathrm{x}}$," however, are too dissimilar to pair with the male chromosomes. Consequently, paternal characters expressed by each generation fail to be incorporated into the $F_{1}$ ova and the two unisexual strains remain perpetual hybrids.

In vertebrate animals selective maturation has not been previously verified either genetically or cytologically, but details of the process have been worked out for a number of insects in the families Margaroidae, Lacanoidae, Sciaridae, Cecidomyidae, and Pediculidae (White, 1954). The means by which chromatin is eliminated varies. In general, oogenesis is normal but in the spermatogonial divisions certain chromosomes or the entire genome of one sex or the other is discarded in a bud of cytoplasm resembling a polar body. Expulsion of certain chromosomes may even occur during early cleavage stages.

With the information now at hand the two examples of unisexuality in the family Poeciliidae can be compared. Basically the two mechanisms are different. In $\mathrm{Mol}$ lienesia formosa, fertilization does not include gametic fusion; hence the phenotype of the offspring is totally dependent on the genotype of the mother; the all-female progeny of Poeciliopsis, however, express characters of both parents. In spite of this basic difference there are ways in which the two systems are alike. In $M$. formosa the egg nucleus contains only maternal chromatin; the same is true in mature ova of Poeciliopsis strains " $\mathrm{C}_{\mathrm{x}}$ " and " $\mathrm{F}_{\mathrm{x}}$ " since the paternal chromatin (for the most part at least, if not in total) is lost during meiosis. In individuals with either type of 
mechanism, the unisexual condition prevents mutations from becoming part of a common gene pool. Any change is restricted to the clone in which it originates. The obligatory heterozygous nature of the unisexual Poeciliopsis, however, would seem to hold certain advantages over the gynogenetic type of Mollienesia in that each generation of " $\mathrm{C}_{\mathrm{x}}$ " or " $\mathrm{F}_{\mathrm{x}}$ " utilizes the genetic variability originating within the bisexual strains. Since these paternal contributions are not incorporated in the " $\mathrm{C}_{\mathrm{x}}$ " and " $\mathrm{F}_{\mathbf{x}}$ " genetic systems but are merely "on loan," the unisexual strains are, in effect, as isolated from their bisexual counterparts as is Mollienesia formosa from its males of $M$. latipinna and $M$. sphenops. It is possible that the selective segregation of Poeciliopsis represents a transition stage to gynogenesis and thence to parthenogenesis, but it is equally possible that these two unisexual mechanisms are merely leftovers from the hybridization of animals with inefficient isolating mechanisms.

If the latter situation obtains, it is difficult to imagine that such a dead-end phenomenon has persisted or could long persist in nature. It, therefore, might still be possible to reconstruct the unisexual strains. Investigations currently being conducted toward this end have been promising; and although a unisexual type has not been produced, male progeny were obtained when " $\mathrm{C}_{\mathrm{x}}$ " was mated to males of a different species group. It is believed that with continued experimentation in this area the " $\mathrm{C}_{\mathrm{x}}$ " and " $\mathrm{F}_{\mathrm{x}}$ " strains will ultimately be synthesized in the laboratory.

\section{ACKNOWLEDGMENTS}

The author wishes to express his deepest gratitude to Dr. Robert $\mathrm{R}$. Miller for suggesting the problem and for giving freely of his time and helpful suggestions throughout this study. The splendid cooperation of Dr. and Mrs. Carl L. Hubbs in supervising the initial handling of live shipments from Mexico made the project feasible.

Aquaria and other equipment were pro- vided by the Department of Fisheries and the Museum of Zoology. Grants from the Horace H. Rackham School of Graduate Studies made available the live stocks used in this study and part of the field expenses for the 1959 expedition to Mexico. A National Science Foundation grant (NSF G-4858) to Dr. Miller provided the author with employment as research assistant and later as research associate in the biosystematic studies of Poeciliopsis, part of which form the basis of this report.

\section{SUMMaRY}

1. The viviparous poeciliid fishes of the genus Poeciliopsis comprise approximately 16 species that chiefly inhabit the Pacific slope of Mexico but occur as far south as Colombia. Two allopatric populations, here designated " $C$ " and " $F$," each have, in addition to normal males and females, an aberrant, unisexual strain. These strains, " $\mathrm{C}_{\mathbf{x}}$ " and " $\mathrm{F}_{\mathbf{x}}$," in five laboratory generations, gave birth only to female progeny. In attempting to determine the mechanism by which all-female broods are produced, the reproductive biology and genetics of both " $\mathrm{C}-\mathrm{C}_{\mathrm{x}}$ " and " $\mathrm{F}-\mathrm{F}_{\mathrm{x}}$ " were investigated.

2. In Poeciliopsis fertilization is internal. The embryos develop within the ovarian follicles by a process of superfetation, whereby two or more stages of embryos occur in the ovary simultaneously. Births occur at intervals of 7 to 14 days, with as many as 34 offspring in a single brood; however, broods of fewer than 12 are more common.

3. Examination of ovaries and brood data collected over the four-year period of this investigation eliminated the possibility that the lack of male offspring from " $\mathrm{C}_{\mathbf{x}}$ " and " $F_{x}$ " females is caused by a lethal system operative on either the gametes, embryos, or juveniles. Genetic data and examination of sectioned gonads provided evidence against sex-inversion. Inheritance of paternal characters by the unisexual type progeny invalidates parthenogenesis or gynogenesis, and polyploidy was rejected on the basis of chromosome counts. 
4. In hybrid crosses between " $\mathrm{C}$ " and " $F$ " there is a high degree of genetic compatibility. Meiotic divisions of the $F_{1}$ progeny are apparently normal, with random segregation of chromosomes. Reciprocal differences in the sex-ratio suggest, however, that the potency of the sex-determining factors of one species exceeds that of the other. There is no genetic or cytological evidence that the bisexual strains have sex chromosomes. It appears that, to a large extent if not completely, sex-determination depends on autosomal genes.

5. Inheritance of a marker gene (dorsalfin spot) in both the bisexual and the unisexual strains bears significantly on the mechanism involved in the production of all-female broods. When crosses involved the bisexual-type female, transmission data indicated autosomal inheritance with incomplete dominance. When the unisexual strains were used in the same crosses, however, the character appeared to be sexlinked with the female heterogametic, WY, and the fin-spot (S) dominant to its allele, no-spot (s). Expression of the character in each "all-female" generation was, therefore, totally dependent upon the S locus of the paternal chromosome. All evidence indicated that the male chromosome is not transmitted through the $F_{1}$ ova but is lost during oogenesis.

6. It is postulated that the nonhomologous or "W" chromosome of " $\mathrm{C}_{\mathrm{x}}$ " and " $\mathrm{F}_{\mathrm{x}}$ " is in reality not a sex-chromosome, but rather one of several chromosomes introduced into the genomes of the unisexual females through hybridization. These chromosomes, which are inherited as a unit, have female-determining factors too strong to be counterbalanced by the paternal factors provided by " $C$ " or " $F$ " males. They furthermore are genetically too dissimilar to pair with the paternal chromosomes during oogenesis. Asynapsis probably results in the expulsion of the paternal chromosomes in a polar body.

7. The only other naturally occurring unisexual vertebrate is Mollienesia formosa, a cyprinodont fish in the same family as
Poeciliopsis. The reproductive mechanisms of these two exclusively female-producing groups, however, are different. In $M$. formosa sperm provided by males of two other species serves only to stimulate the ova into development, there being no gametic fusion, whereas in Poeciliopsis fertilization is normal and paternal characters are expressed by the offspring.

\section{Literature Cited}

AIDA, T. 1936. Sex reversal in Aplocheilus latipes and a new explanation of sex differentiation. Genetics, 21: 136-153.

BööK, J. A. 1940. Triploidy in Triton taeniatus Laur. Heridatas, 26: 107-114.

Cavalcanti, A. G. L., D. N. Falcäo, and L. E. Castro. 1957. "Sex-ratio" in Drosophila prosaltens--a character due to interaction between nuclear genes and cytoplasmic factors. Amer. Nat., 90: 327-329.

Essenberg, J. M. 1923. Sex-differentiation in the viviparous teleost Xiphophorus helleri Heckel. Biol. Bull., 45: 46-97.

Friesz, E. 1933. Untersuchungen über die Geschlechtsumkehr bei Xiphophorus helleri Heckel. Roux Arch. Entw. Mech. Organ., 129: 255355.

Goldschmid, R. 1931. Analysis of intersexuality in the gypsy moth. Quart. Rev. Biol., 6: $125-142$.

- 1932. Untersuchungen zur Genetik der geogrophischen Variation. III. Abschliessendes über die Geschlechtsrassen von Lymantria dispar. Roux Arch. Entw. Mech. Organ., 126: $277-324$.

- 1934. Lymantria. Bibliogr. Genet. II: 1-186.

Gordon, M. 1952. Sex determination in $X i-$ phophorus (Platypoecilus) maculatus. III. Differentiation of gonads in platyfish from broods having a sex ratio of three females to one male. Zoologica, 37: 91-100.

- 1957. Physiological genetics of fishes. In Physiology of Fishes. Vol. 2. Acad. Press Inc., New York. pp. 431-501.

Hubss, C. L. 1955. Hybridization between fish species in nature. Syst. Zool., 4: 1-20.

- AND L. C. HubBs. 1932. Apparent parthenogenesis in nature, in a form of fish of hybrid origin. Science, 76: 628-630.

— AND —. 1946. Breeding experiments with the invariable female, strictly matroclinous fish, Mollienisia formosa. Rec. Gen. Soc. Am., No. 14: 48.

Kosswig, C. 1954. Zum Geschlechtsbestimungsproblem bei den Zahnkarpfen. Rev. Fac. Sci. Univ. Istanbul, 19: 187-190. 
Kosin, I. L., I, Sato, and H. Nagra. 1958. Studies of parthenogenesis in the domestic turkey and chicken. Eleventh World's Poultry Congress, Mexico City, Mexico.

KRUmholz, L. A. 1948. Reproduction in the western mosquitofish, Gambusia affinis affinis (Baird and Girard), and its use in mosquito control. Ecol. Monogr., 18: 1-43.

KupKa, E. 1948. Chromosomale Verschiedenheiten bei schweitzerischen Coregonen (Felchen). Rev. Suisse Zool., 55: 285-293.

LIEder, U, 1955. Männschenmangel und natürliche Parthenogenese bei der Silberkarausche Carassius auratus gibelio. Naturwissenschaften, 42: 590 .

Makino, S. 1951. An atlas of the chromosome numbers in animals. Iowa State College Press, pp. 1-290.

Miller, R. R. 1960. Four new species of viviparous fishes, genus Poeciliopsis, from northwestern Mexico. Occ. Papers Mus. Zool. Univ. Mich., No. 619: 1-11.

AND R. J. Schultz. 1959. All-female strains of the teleost fishes of the genus Poeciliopsis. Science, 130: 1,656-1,657.

Muller, H. J. 1947. The production of mutations. Jour. Hered., 28: 259-270.

Olsen, M. W., and S. J. Marsden. 1954. Natural parthenogenesis in turkey eggs. Science, 120: $545-546$.
Öztan, N. 1954. Cytological investigation of the sexual differentiation in the Anatolian cyprinodontids. Rev. Fac. Sci. Univ. Istanbul, 19: $245-280$.

Poole, H. K. 1959. The mitotic chromosomes of parthenogenetic and normal turkeys. Jour. Hered., 50: 151-154.

StoLK, A. 1958. Pathological parthenogenesis in viviparous toothcarps. Nature, 181: 1,660.

Sturtevant, A. H. 1920. Genetic studies on Drosophila simulans. I. Introduction. Hybrids with Drosophila melanogaster. Genetics, 5: 488-500.

Suomadainen, E. 1950. Parthenogenesis in animals. Advanc. Genet., 3: 193-253.

Svärdson, G. 1943. Studien über den Zusammenhang zwischen Geschlechtsreife und Wachstum bei Lebistes. Meddel. Rept. Swedish State Inst. Freshw. Fish. Res. Drottningholm, 2I: $1-48$.

- 1945. Chromosome studies in Salmonidae. Ibid., 23: 1-151.

Turner, C. L. 1937. Reproductive cycles and superfetation in poeciliid fishes. Biol. Bull., 72: $145-164$.

White, M. J. D. 1954. Animal cytology and evolution. Cambridge Univ. Press. 454 pp.

Wiсквом, T. 1943. Cytological studies in the family Cyprinodontidae. Hereditas, 29: 1-24.

Winge, Ö., and E. Ditlevsen. 1947. Color inheritance and sex determination in Lebistes. Heredity, 1: 65-83. 